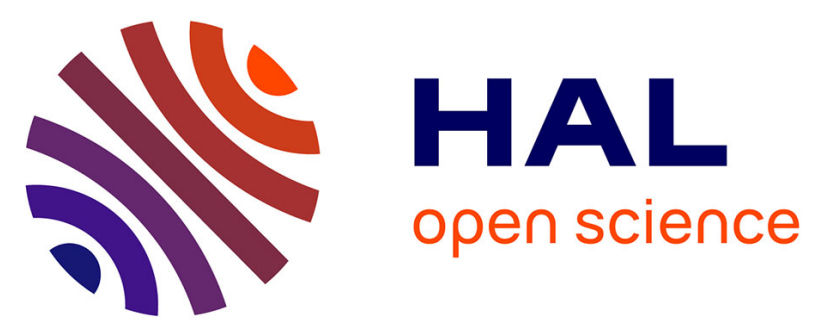

\title{
Novel insights from coleopteran and pollen evidence into the Lateglacial/Holocene transition in Aubrac, French Massif Central
}

Philippe Ponel, Frédéric Guiter, Emmanuel Gandouin, Christine Paillès, Patrick Rioual, Morteza Djamali, Valérie Andrieu-Ponel, Michelle Leydet, Nathalie van Der Putten, Jacques-Louis De Beaulieu

\section{To cite this version:}

Philippe Ponel, Frédéric Guiter, Emmanuel Gandouin, Christine Paillès, Patrick Rioual, et al.. Novel insights from coleopteran and pollen evidence into the Lateglacial/Holocene transition in Aubrac, French Massif Central. Palaeogeography, Palaeoclimatology, Palaeoecology, 2016, 463, pp.83-102. 10.1016/j.palaeo.2016.09.020 . hal-01444688

\author{
HAL Id: hal-01444688 \\ https://hal.science/hal-01444688
}

Submitted on 6 Oct 2020

HAL is a multi-disciplinary open access archive for the deposit and dissemination of scientific research documents, whether they are published or not. The documents may come from teaching and research institutions in France or abroad, or from public or private research centers.
L'archive ouverte pluridisciplinaire HAL, est destinée au dépôt et à la diffusion de documents scientifiques de niveau recherche, publiés ou non, émanant des établissements d'enseignement et de recherche français ou étrangers, des laboratoires publics ou privés. 


\title{
Novel insights from coleopteran and pollen evidence into the Lateglacial/ Holocene transition in Aubrac, French Massif Central
}

\author{
Philippe Ponel ${ }^{\mathrm{a}, *}$, Frédéric Guiter ${ }^{\mathrm{a}}$, Emmanuel Gandouin ${ }^{\mathrm{a}}$, Christine Pailles ${ }^{\mathrm{b}}$, Patrick Rioual ${ }^{\mathrm{c}}$, \\ Morteza Djamali ${ }^{a}$, Valérie Andrieu-Ponel ${ }^{a}$, Michelle Leydet ${ }^{a}$, \\ Nathalie Van der Putten ${ }^{\mathrm{d}}$, Jacques-Louis de Beaulieu ${ }^{\text {a }}$ \\ a IMBE, Aix Marseille Université, Univ Avignon, CNRS, IRD, Technopôle Arbois Méditerranée, Bât. Villemin, BP 80, F-13545 Aix-en-Provence Cedex 04, France

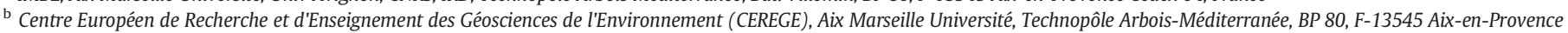 \\ Cedex 04, France \\ c Institute of Geology and Geophysics, Chinese Academy of Sciences, P.O. Box 9825, Beijing, China \\ d Faculty of Science, Lund University, Box 118, SE-22100 Lund, Sweden
}

\section{A R T I C L E I N F O}

\section{Article history:}

Received 4 May 2016

Received in revised form 22 September 2016

Accepted 26 September 2016

Available online 30 September 2016

\section{Keywords:}

Lateglacial

Holocene

Coleoptera

Pollen

Massif central

Palaeoenvironments

\begin{abstract}
A B S T R A C T
The aim of this study is to describe the environmental and climate changes that occurred in the mountains of Aubrac at the transition between the Lateglacial and the Holocene, from a comparative analysis of fossil Coleoptera and pollen, and a series of $23{ }^{14} \mathrm{C}$ dates. The changes affecting the ecological categories of Coleoptera lead to a division of the sequence into 5 beetle assemblage zones (BAZ): the lowermost BAZ A is characterized by extremely poor assemblages (periglacial environment); BAZ B (Oldest Dryas and Lateglacial Interstadial) is marked by regular occurrences of taxa associated with open environments, aquatic taxa associated with running and highly oxygenated water, and cold adapted taxa with relatively low numbers; BAZ C (Younger Dryas) corresponds to two important events: a particular abundance of cold adapted taxa and a marked decrease of running water taxa, beetles associated with herbaceous vegetation and open environments are also well represented; BAZ D (Early Holocene) corresponds to the total disappearance of cold adapted taxa; the transition BAZ C/BAZ D is marked also by a dramatic peak of running water taxa; the uppermost BAZ E (Early/Mid Holocene) is marked by a total absence of running water taxa which are replaced by standing water or taxa tolerant of a range of water conditions, a particular abundance of wetland taxa, and taxa associated with herbaceous vegetation and open environments. Beetle and pollen data suggest that the harsh climatic conditions prevailing in the Aubrac mountains did not allow warm dependent fauna and trees to establish during the Lateglacial Interstadial, at least in the Roustières region, and that wide open landscapes occupied the plateau at that time. The Older Dryas, a cold spell previously recorded at La Taphanel (Cantal), is not visible in the Roustières record, probably because of the higher altitude at Roustières, whereas the Younger Dryas is strongly expressed. During the Holocene, concordant beetles and pollen data enable to reconstruct the rapid recolonization of the plateau by mesophilous trees (Ulmus, Quercus), suggesting the possible presence of refugia to the southern slopes of the Aubrac plateau. Insect/pollen comparisons provide evidence for hydrological changes in the former lake of Roustières and suggest that lacustrine water level changes often used as indicator of precipitation regime changes should be taken with caution.
\end{abstract}

\section{Introduction}

During the three last decades, considerable progress has occurred in our knowledge of (1) climate and environmental changes during the

\footnotetext{
* Corresponding author

E-mail addresses: philippe.ponel@imbe.fr (P.Ponel), frederic.guiter@imbe.fr (F. Guiter), emmanuel.gandouin@imbe.fr (E. Gandouin), pailles@cerege.fr (C. Pailles), prioual@mail.igcas.ac.cn (P. Rioual), morteza.djamali@imbe.fr (M. Djamali), valerie.andrieu-ponel@imbe.fr (V. Andrieu-Ponel), michelle.leydet@imbe.fr (M. Leydet), nathalie.van_der_putten@geol.lu.se (N. Van der Putten), jacques-louis.debeaulieu@orange.fr (J.-L. de Beaulieu).
}

Lateglacial/Holocene transition in western Europe and (2) global mechanisms driving these events thanks to multidisciplinary studies on both well-dated palaeoecological and $\partial^{18} \mathrm{O}$ records (Lotter et al., 2000; Ammann, 2000; Schwander et al., 2000; Litt et al., 2003; Van Raden et al., 2013; Rasmussen et al., 2014; Birks et al., 2014; Moreno et al., 2014). For instance, they highlighted a number of rapid climate oscillations (not evidenced previously by pioneer palynological studies) which punctuate the upper Pleistocene and Holocene history. During this period, climate has been marked by series of abrupt changes between cold and warm phases. Following deglaciation, a sudden rise in temperature occurred at ca $14,700 \mathrm{cal}$. BP, taking place within half a 
century (Rasmussen et al., 2006), characterizing the onset of the Lateglacial interstadial (LGI, also called Bølling/Allerød, corresponding to the Greenland Interstadial GI-1 following Björck et al., 1998). This period was also interspersed by at least three short minor cold oscillations, such as "Intra Bølling Cold Period" (IBCP), the "Aegelsee oscillation": Gl1d (defined by Lotter et al., 1992 and corresponding to the Older Dryas), the "Intra Allerød Cold Period" (IACP, Lehman and Keigwin, 1992) between 13,300 and 13,100 cal. BP (Gl-1b, also called the Gerzensee oscillation firstly described in Switzerland, see Eicher and Siegenthaler, 1976, von Grafenstein et al., 2013).

Lastly, the Allerød/YD transition occurred rapidly as is illustrated in ice core records (Dansgaard et al., 1993; Grootes et al., 1993; Stuiver et al., 1995) by an abrupt and intense cooling (Greenland Stadial 1, GS-1), which profoundly affected ecosystems at a global scale. Therefore, as is suggested by the pioneering work of Siegenthaler et al. (1984), similarities between global isotope and terrestrial records suggest that the intense climate variability which characterized the LGI occurred synchronously over wide areas, especially in northern hemisphere (van Raden et al., 2013). Biotic responses to these climatic changes have also been reflected by several palaeoecological records (Feurdean et al., 2008; Ammann et al., 2013, Brooks and Heiri, 2013; Munoz-Sobrino et al., 2013; Birks et al., 2014) showing that vegetation response might also depend on ecological processes and biogeographi$\mathrm{cal} /$ topographical contexts. Moreover, time-shifted ecological responses can be observed following cold or warm episodes raising the question of resiliency of each living community: vegetation might then be expected to have a lagged response to climate change compared to animal communities.

It must also be noted that Lateglacial climate variability is generally characterized by large amplitude shifts in temperature. A key underpinning issue is how quickly terrestrial ecosystems, especially in mountain areas, responds to such large and rapid climate changes. Shakun and Carlson (2010) already posed this question in an attempt to characterize at a global scale the timing and spatial pattern of climate change during the last deglaciation.

Among the available archives, mountain lakes and peat-bog sediments represent a valuable source of past climate and environmental records through their fossil content. The French Massif Central, a large mountain close to the Atlantic Ocean between latitudes $44^{\circ}$ and $46^{\circ}$ north, constitutes an exceptional reservoir of palaeo-environmental archives, due to a large number of volcanic and glacial palaeolakes and bogs. In the eighties, pollen analyses of numerous sites has provided valuable information on the vegetation dynamics by defining a robust framework for the regional vegetation history (Beaulieu et al., 1988). Nevertheless the palaeoenvironmental reconstructions proposed in this pioneering work suffered from poor ${ }^{14} \mathrm{C}$ chronological control and lack of multi-proxy analyses.

This situation has justified a new coring campaign aimed at analyzing more precisely the climatic transition from Lateglacial to Holocene and its palaeoecological consequences in one of the most promising sites of the Aubrac sub-massif (South of Massif central), the "Brameloup" peat bog (named here more accurately "Les Roustières"), explored by Beaulieu et al. (1985). Unfortunately, the Lateglacial part of this profile remained undated. The objective of the project ECLIPSE PaleAubrac was to study in parallel diatoms, chironomids, pollen and Coleoptera in a sound chronological framework. The results of this multi-proxy approach will be presented in several papers: diatoms vs. chironomids (Gandouin et al., 2016), and pollen vs. Coleoptera (present paper). It must be noted that Quaternary coleopteran analyses are very rare in Massif Central. La Taphanel is the closest $\left(2^{\circ} 40^{\prime} 54^{\prime \prime} \mathrm{E}, 45^{\circ} 16^{\prime} 24^{\prime \prime} \mathrm{N}\right.$, $975 \mathrm{~m}$ a.s.l., located $70 \mathrm{~km}$ north-west of "Les Roustières") and is the sole site including a comparison between pollen and beetle records (Ponel and Coope, 1990). Coleopteran fossils may be considered as one of the most sensitive palaeoecological and palaeoclimatic indicators (Coope, 1998, 2004). This is a species-rich group with about 11,650 species in France (Tronquet, 2014), each species being adapted to a particular ecological niche. Moreover, coleopteran fossils can very often be identified to the species level and thus are potentially able to provide a wealth of palaeoenvironmental and palaeoclimatic information inferred from the available literature dealing with the ecology of modern species.

The objectives of this new investigation are therefore twofold:

-To place in a sound chronological context the main climatic and environmental changes in Aubrac, from the end of the last glaciation to the mid-Holocene, using a large set of ${ }^{14} \mathrm{C}$ dates and a well-established agedepth model,

-To re-interpret these changes using several independent proxies enabling to shed original light on this complex period, which until now and in this region was documented by pollen data only.

This paper is therefore focused on the coleopteran record and a cross-comparison with pollen data, at the turning point between the Last Glacial and the Holocene.

\section{Study area}

\subsection{The Aubrac plateau: location and geomorphological background}

The Aubrac plateau is a large granitic and basaltic plateau located to the south of the French Massif Central. It stretches on approximately 38,000 ha from the volcanic Cantal massif in the NW to the flat limestone region of Causse de Sauveterre in the SE, with altitudes ranging from $1000 \mathrm{~m}$ to $1471 \mathrm{~m}$ at "signal de Mailhebiau". This vast area is made of a long line of highest elevation, the monts d'Aubrac, with steep slopes reaching in the south the Lot valley and calcareous "causses". To the east and north east, gentle slopes reach the Truyère Valley. The bedrock is made of metamorphic and granitic rocks, covered by a basaltic layer formed during the Villafranchian eruptive episode (Colin, 1966). On these two substrata are scattered abundant and sometimes thick glacial and periglacial deposits, attributed by Poizat and Rousset (1975) to three episodes of glaciation, covering about 30,000 ha. Glacial geomorphology has resulted in numerous closed depressions now occupied by lakes, mires and peat bogs, whose sediment archives were explored by one of the pioneer French palynologists $G$. Lemée (1944). We must also mention the study of Lang and Trautman (1961) on Lac de Salhiens, which probably represents the first "modern" pollen study in France. Latter Beaulieu et al. (1985) published the pollen analyses of 10 sites scattered on the plateau, three of which present continuous records since the end of the last glaciation.

\subsection{Vegetation and climate}

Most of the Monts d'Aubrac are located in the montane zone, potentially occupied by Fagus sylvatica forests on volcanic soil, and mixed forests with Fagus sylvatica and Pinus sylvestris on granitic soil. However a long history of intense pastoral use has deeply modified this vegetation, which is today dominated by Calluna vulgaris or Cytisus purgans heathlands, and, above all, by summer pastures (Doche, 1976). At lower altitudes oak forests with Quercus pedunculata, Quercus sessiflora, and Quercus pubescens are present. Numerous wetlands and peat bogs with relictual flora and fauna, mainly arctic-alpine, are located on the Aubrac plateau and help to make this region an area of great ecological value (Puech, 2010). On the Aubrac plateau, rather high mid-altitudes (higher summit at $1471 \mathrm{~m}$ a.s.l.) generate cold winter temperatures ( $\mathrm{T}$ $\min =-5^{\circ} \mathrm{C}$ to $0^{\circ} \mathrm{C}$ ). Heavy rainfalls are induced by humid winds coming both from the Mediterranean and the Atlantic (average annual rainfall $=1100$ to $1800 \mathrm{~mm}$, Météo France (2003)), therefore snowfalls are particularly important on the plateau (more than 50 days per year).

\subsection{The site}

To the N-W of the Malbouzon village (Fig. 1), the large peat bog Las

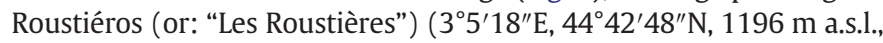


25 ha) occupies a former glacial hollow surrounded by low hills (Brameloup, La Chaumette, Magazone, $1264 \mathrm{~m}$ a.s.l.) and drained by the outlet "des Roustières". According to Poizat and Rousset (1975), two moraine ridges close the depression to the $\mathrm{S}-\mathrm{W}$, originally a palaeolake occupied today by a peat bog. As indicated above, the potential vegetation around the site is beech forest (Doche, 1976), but a long land use history is attested to by the plateau's typical grid pattern of large meadows enclosed by rough granitic stone walls. On the hills the poorest soils are covered by Calluna vulgaris and Genista purgans heathlands. The Roustières bog itself is covered by a mosaic of different mire vegetation types with Carex limosae in the wetter zone, to raised bog with different Sphagnum species, sometimes invaded by Calluna and by moss blankets. The margins are occupied by wet meadows with abundant Scirpus caespitosus. Arctic-alpine relictual plants include Ligularia sibirica, Les Roustières being the southernmost outpost of its range (Puech, 2010).

\section{Material and methods}

\subsection{Field work}

Les Roustières peat bog was sampled in June 2005 with a Russian corer, allowing cores of $1-\mathrm{m}$ long and 7-cm wide to be obtained. 14 profiles were extracted from the peat bog, in order to detect the area where the Lateglacial sedimentation is the thickest, to confirm previous corings (Beaulieu et al., 1985). Four parallel profiles were taken from this area, three of them used for multi-proxy analyses, the fourth being reserved as archive for future investigations.

\subsection{Lithology}

The lithology of the profile may be roughly divided into 3 main units. The lowermost part (approximately $1000-900 \mathrm{~cm}$ depth) is made of clayey deposits. This layer is overlain $(900-600 \mathrm{~cm})$ by $3 \mathrm{~m}$ of claygyttja deposits. The upper layer (600 $\mathrm{cm}$ to surface) is made of a thick accumulation of dense and homogenous fibrous peat, interrupted by a sandy layer at $320 \mathrm{~cm}$ (Fig. 2).

\subsection{Chronology}

Twenty two sediment samples were dated using the conventional radiocarbon method (Table 1) at LMC14 Saclay (sample code SacA) and at Poznan Radiocarbon Laboratory (sample code Rous). The dates were calibrated using the Clam software (Blaauw, 2010) associated with the statistical software R (version 3.0.1) (R Core Team, 2012) and the non-marine (IntCal09) radiocarbon calibration (Reimer et al.,

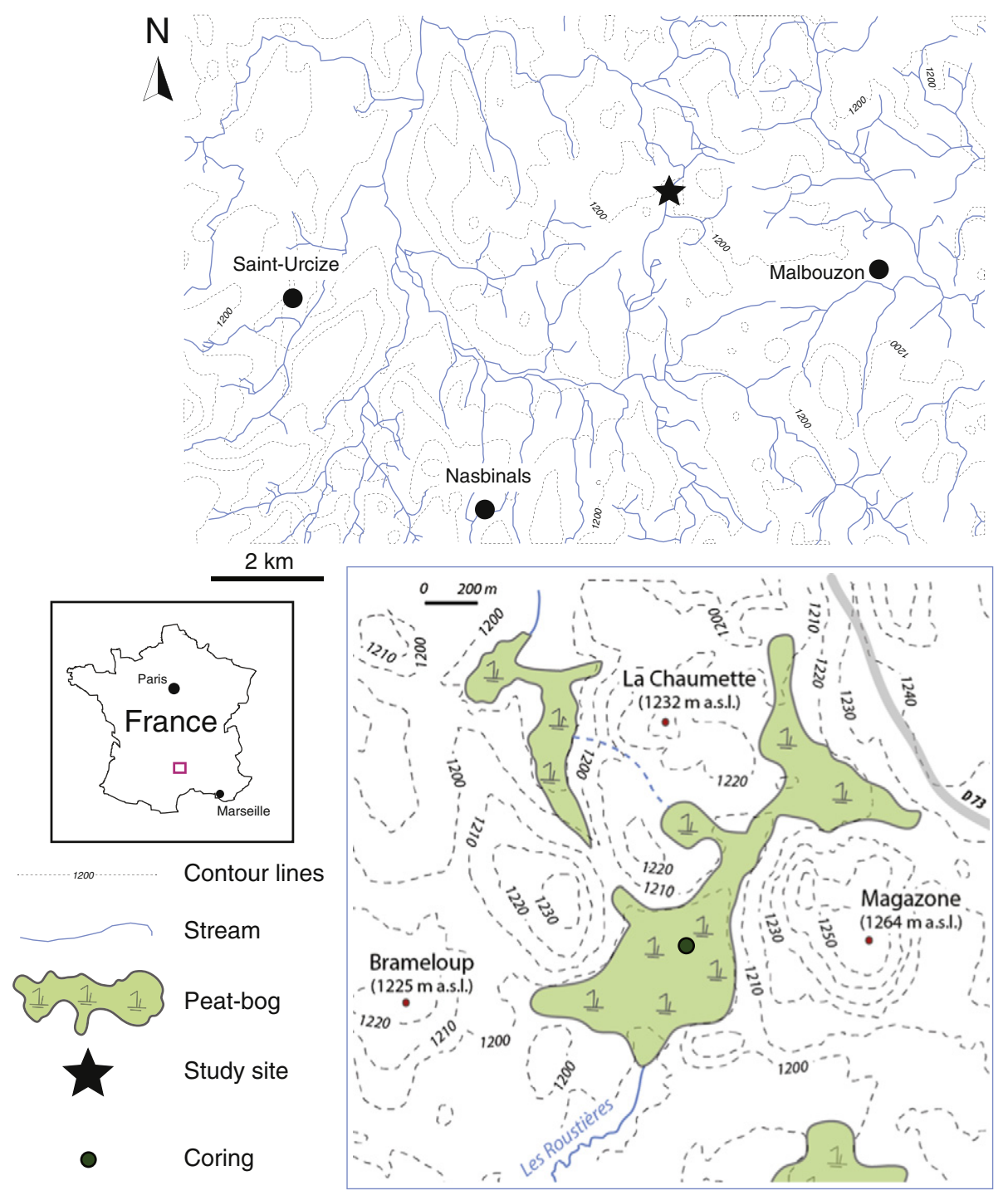

Fig. 1. Location of the study site. 


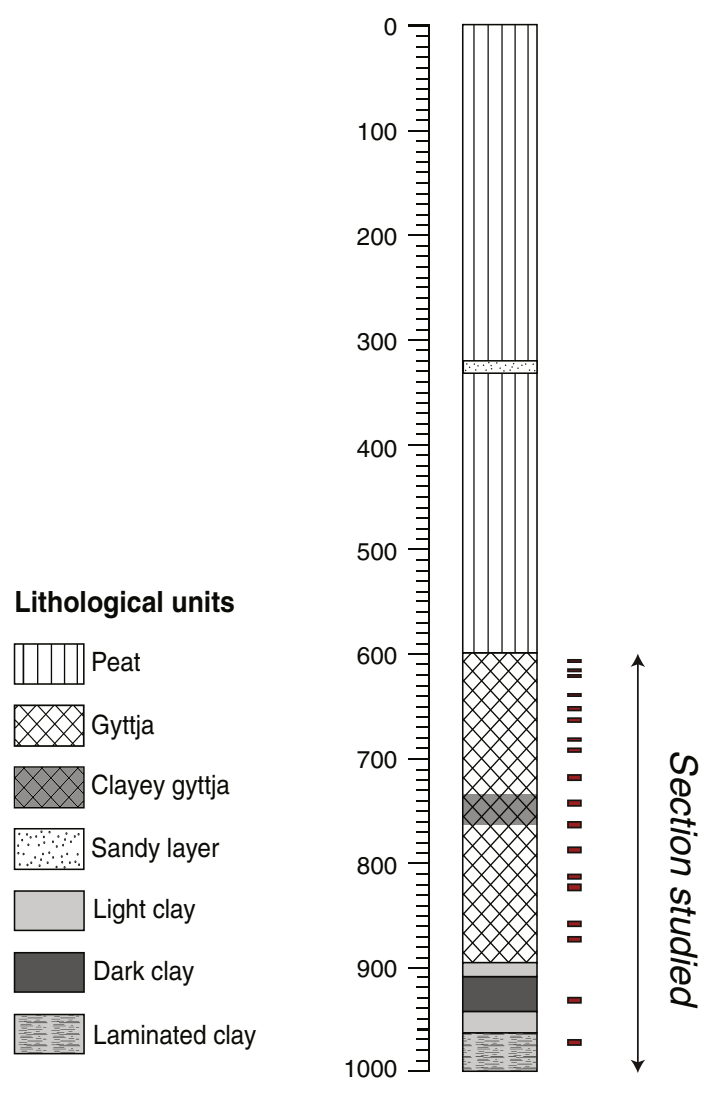

Depth $(\mathrm{cm})$

Fig. 2. Lithology of the composite cores from the thickest deposits from the central area of Roustières peat bog. Red rectangles mark the stratigraphical location of ${ }^{14} \mathrm{C}$ samples.

2013). The dates are calculated at 2 standard deviations. The age-depth model (solid black line) presented in the results was developed using a smooth spline interpolation ( $\mathrm{spar}=0.3$ and 10,000 iterations) between dated levels with the same software (Fig. 3). The upper et lower sections

Table 1

Radiocarbon datings.

\begin{tabular}{lllll}
\hline Sample code & Depth $(\mathrm{cm})$ & Type of sample & Age uncal BP & Age cal BP (2 sigmas) \\
\hline Rous-6 & $600-601$ & Peat & $8800 \pm 60$ & $9610-10,153$ \\
SacA 10451 & $607-608$ & Gyttja & $8770 \pm 30$ & $9634-9906$ \\
SacA 10452 & $615-618$ & Gyttja & $8605 \pm 30$ & $9526-9628$ \\
SacA 10453 & $620-622$ & Gyttja & $8830 \pm 35$ & $9706-10,150$ \\
SacA 10454 & $637-640$ & Gyttja & $8785 \pm 35$ & $9633-10,114$ \\
SacA 10455 & $650-653$ & Gyttja & $9405 \pm 35$ & $10,557-10,731$ \\
SacA 10456 & $660-664$ & Gyttja & $9585 \pm 45$ & $10,745-11,128$ \\
SacA 10457 & $680-681$ & Gyttja & $9705 \pm 35$ & $10,888-11,218$ \\
SacA 10458 & $690-692$ & Gyttja & $9615 \pm 35$ & $10,782-11,166$ \\
SacA 10459 & $715-720$ & Gyttja & $10,090 \pm 35$ & $11,404-11,957$ \\
Rous-5 & $730-735$ & Gyttja & $10,200 \pm 60$ & $11,628-12,108$ \\
SacA 10460 & $745-750$ & Gyttja & $10,635 \pm 40$ & $12,446-12,682$ \\
Rous-4 & $755-760$ & Gyttja & $10,950 \pm 60$ & $12,648-13,063$ \\
SacA 10461 & $760-765$ & Gyttja & $10,965 \pm 40$ & $12,657-13,054$ \\
SacA 10463 & $810-815$ & Gyttja & $10,225 \pm 40$ & $11,769-12,086$ \\
SacA 10464 & $820-825$ & Gyttja & $11,190 \pm 40$ & $12,902-13,234$ \\
Rous-3 & $835-840$ & Gyttja & $11,020 \pm 60$ & $12,705-13,092$ \\
SacA 10465 & $855-860$ & Gyttja & $11,530 \pm 40$ & $13,268-13,477$ \\
SacA 10466 & $870-875$ & Gyttja & $12,090 \pm 45$ & $13,789-14,081$ \\
Rous-2 & $885,5-900,5$ & Gyttja & $12,810 \pm 60$ & $14,909-15,841$ \\
SacA 10468 & $930-935$ & Gyttja & $13,800 \pm 50$ & $16,742-17,075$ \\
SacA 10469 & $970-975$ & Gyttja & $14,360 \pm 50$ & $17,148-17,803$ \\
& & & &
\end{tabular}

of the age-depth curve represented by a dashed line were extrapolated beyond dated levels.

\subsection{Subsampling and sample processing}

After subsampling for pollen analyses and dating, each reference profile was cut for insect macrofossil analyses into 22 slices $(20 \mathrm{~cm}$ thick on average), and equivalent sediment samples from the 3 profiles were lumped together according to stratigraphic features, in order to obtain enough material. Each composite sample is about $1300 \mathrm{~cm}^{3}$ in volume. The 22 insect samples span continuously the $4.45 \mathrm{~m}$ sedimentary profile from the rocky bottom $(9.95 \mathrm{~m})$ to level $5.50 \mathrm{~m}$. This section was selected to cover the Lateglacial oscillations, according to the palynostratigraphy from previous pollen study (Beaulieu et al., 1985).

\subsection{Pollen analysis}

Pollen extraction was carried out according to the classical protocol of Faegri and Iversen (1975). A minimum of 300 pollen grains per sample were identified and the results are shown as percentages of the terrestrial vascular pollen sum. Aquatics are represented in concentrations (number/ml). Fig. 4 (representing a simplified pollen diagram) is drawn with $C^{2}$ software (Juggins, 2003). Table 2 presents a summary description of Local Pollen Assemblages Zones (LPAZ) designed with Rioja package (Juggins, 2015) by using depth-constrained cluster analysis (based on Coniss algorithm).

\subsection{Coleoptera analysis}

The insect fossils were extracted using the method recommended by Coope (1986): wet sieving over a $300 \mu \mathrm{m}$ sieve, paraffin flotation, final sorting under a binocular microscope. The insect remains were preserved in alcohol. Identification was by direct comparison with specimens from a modern reference collection. In the insect table (see Table 3 in supplementary material) the numbers opposite each taxon indicate the minimum number of individuals (NMI) per sample level. Unless otherwise stated, the ecological and climatic interpretation of the fossil coleopteran assemblages is derived from Koch (1989-1992). The Coleoptera are grouped into ecological categories according to their preferred habitat and presented on a synthetic diagram (Fig. 5) drawn with $C^{2}$ software (Juggins, 2003).

\section{Results}

\subsection{Age-depth modelling}

The 2-sigma envelop of the age-depth model encompasses $18{ }^{14} \mathrm{C}$ ages, the 4 remaining dates may be rejected (Fig. 3 ). The latter are "too young" considering the age-depth model, and it can be assumed that small roots may have contributed to these young ages although systematic sorting for each ${ }^{14} \mathrm{C}$ sample has been carried out with care under binocular. A rise in sedimentation rate at ca 13,000 cal. BP is particularly striking since about one meter of gyttja has been deposited during between ca 4 and 7 centuries (according to the age-depth model intervals at 2 sigmas). This section is marked by biogenic sedimentation without any detrital coarse input. Therefore, this episode of rapid accumulation was not due to any erosion process but could be linked to an increase of lake productivity. This point will be discussed later. Lastly, the age/ depth model will be compared with the palynostratigraphy of Roustières pollen record. The chronology obtained by the age/depth model above $600 \mathrm{~cm}$ and below $975 \mathrm{~cm}$ (dashed line) remains questionable, considering that these sections of the curve were extrapolated beyond dated samples. 


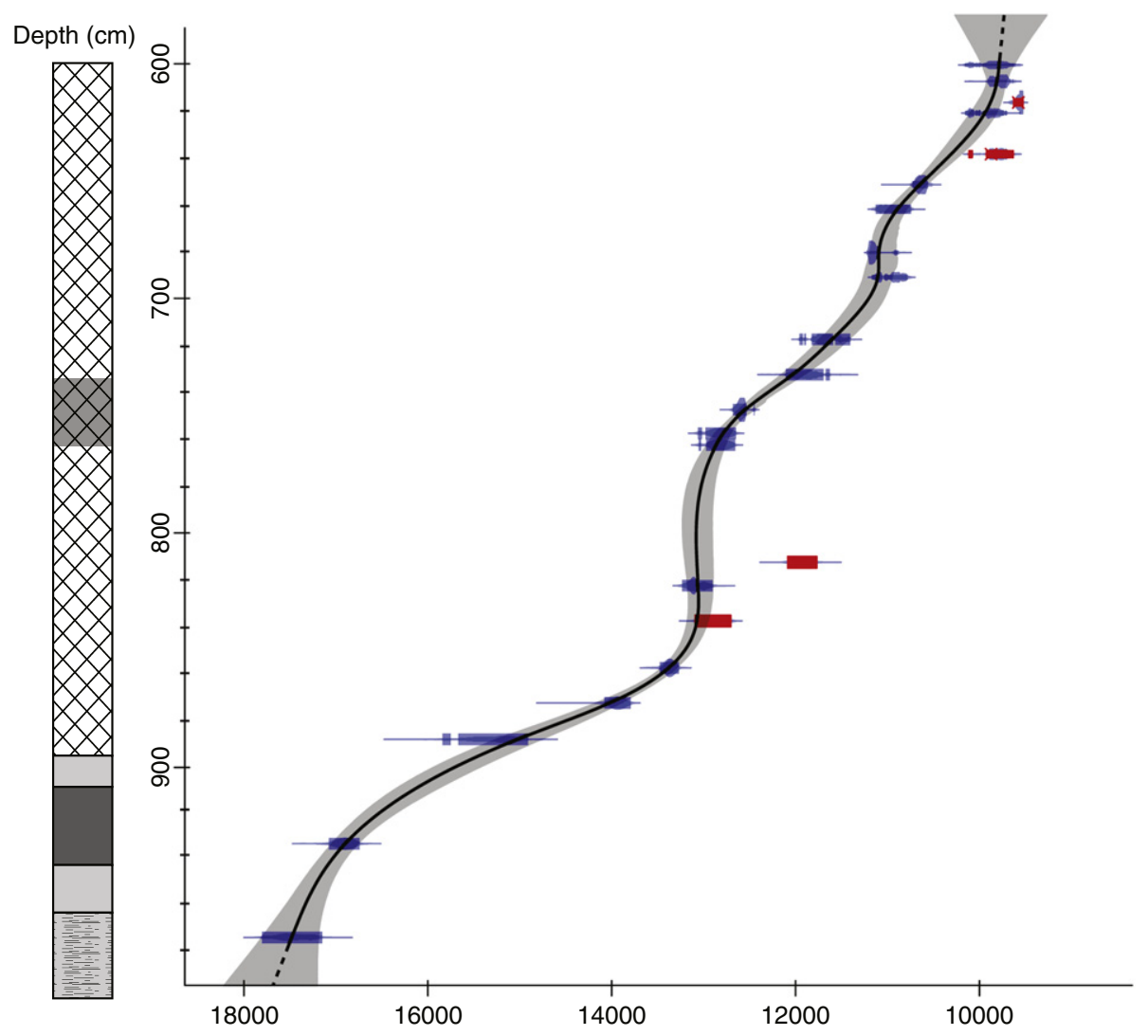

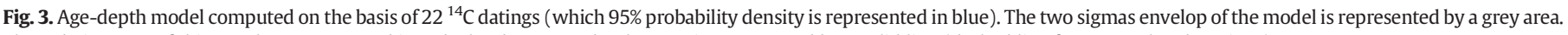
The 4 datings out of this envelop are reported in red. The "best" age-depth curve is represented by a solid line (dashed line for extrapolated sections).

\subsection{Pollen analysis and vegetation history}

\subsubsection{Previous studies on the vegetation history of Aubrac since the last glacial}

Among the 11 sites studied in Aubrac by Beaulieu et al. (1985), only 3 present lacustrine deposits spanning the end of the Pleniglacial and Lateglacial (Bonnecombe 2, La Chaumette and Brameloup (="Les Roustières")). La Chaumette is the only Lateglacial site documented by ${ }^{14} \mathrm{C}$ dates. Thus the chronology proposed by the authors was largely based on palyno-stratigraphic similarities with dated pollen records from other sites in Massif Central (Beaulieu et al., 1988). At Brameloup the authors attribute the lower part of the lacustrine infilling to the end of the last Pleniglacial. It postdates the melting of a local ice cap. The lowest pollen spectra contain abundant pre-Würmian temperate trees, including Carya, Taxodium, Aesculus. They were probably washed down in tills that reworked Neogene and Pleistocene deposits. As everywhere in Massif Central, the oldest Dryas is characterized by an expansion of steppe (tundra-steppe) taxa. Here the transition to the Lateglacial Interstadial (LGI) is marked by a rise of Ranunculus batrachium pollen type. The rise of Juniperus followed by Betula is considered as the inception of the LGI. The second part of the LGI is marked by a moderate increase in Pinus pollen frequencies suggesting small pine stands in the surrounding, or forest development at lower altitude on the Aubrac margins. Everywhere on the Massif Central, the whole LGI is characterized by a very poor forest cover (Beaulieu et al., 1988). Of the three Lateglacial sequences from Aubrac, Brameloup (="les Roustières") is the only one which presents a convincing record of the Younger Dryas with a sharp increase of Artemisia and other steppe elements. This evidence and the thickness of the pre-Holocene sediments were one of the main arguments used to initiate new research at this site. Past vegetation changes reconstructed from our pollen study are quite similar to the major stages of Lateglacial/Holocene recolonization described in previous regional studies (Beaulieu et al., 1985, 1988).

\subsubsection{LPAZ 1 (Table 2): Late pleniglacial}

First, it is noticeable that the base of the pollen record (LPAZ 1) is characterized by pollen assemblages with significant percentages of mesophilous taxa, such as Abies and Fagus but more importantly with occurrences of Pterocarya, an exotic tree which is a palynostratigraphical marker of Middle Pleistocene in Europe (Beaulieu et al., 2001) (Fig. 4). Therefore, the 4 basal pollen spectra must be considered as an evidence of pollen grains reworked by glaciers from old interglacial sediments (prior to the OIS 5) and redeposited into a "periglacial lake" (as suggested by basal laminated clay, Fig. 2) during the last Pleniglacial (Beaulieu et al., 1985). This hypothesis is also supported by the age/depth model. In the following paragraphs, ages will be presented by the intervals at 2 sigmas.

\subsubsection{LPAZ 2a-LPAZ 2b: Oldest Dryas}

Around 17,139-17,567 cal. BP (according to the age-depth model), the disappearance of reworked pollen grains along with sharp increase of herbs percentages (such as Poaceae, Caryophyllaceae and Artemisia) marks classically the onset of the Oldest Dryas, while Pinus curve shows significant lowering (Beaulieu et al., 1985). These pollen assemblages indicate that cold steppic grasslands were developing close to the site (LPAZ 2a), certainly on poorly-developed soil. The clayey sedimentation during this period also indicates that the lake was under detrital regime. LPAZ $2 \mathrm{~b}$ is marked by the persistence of cold tundrasteppe assemblages while pine percentages remains below $20 \%$. 


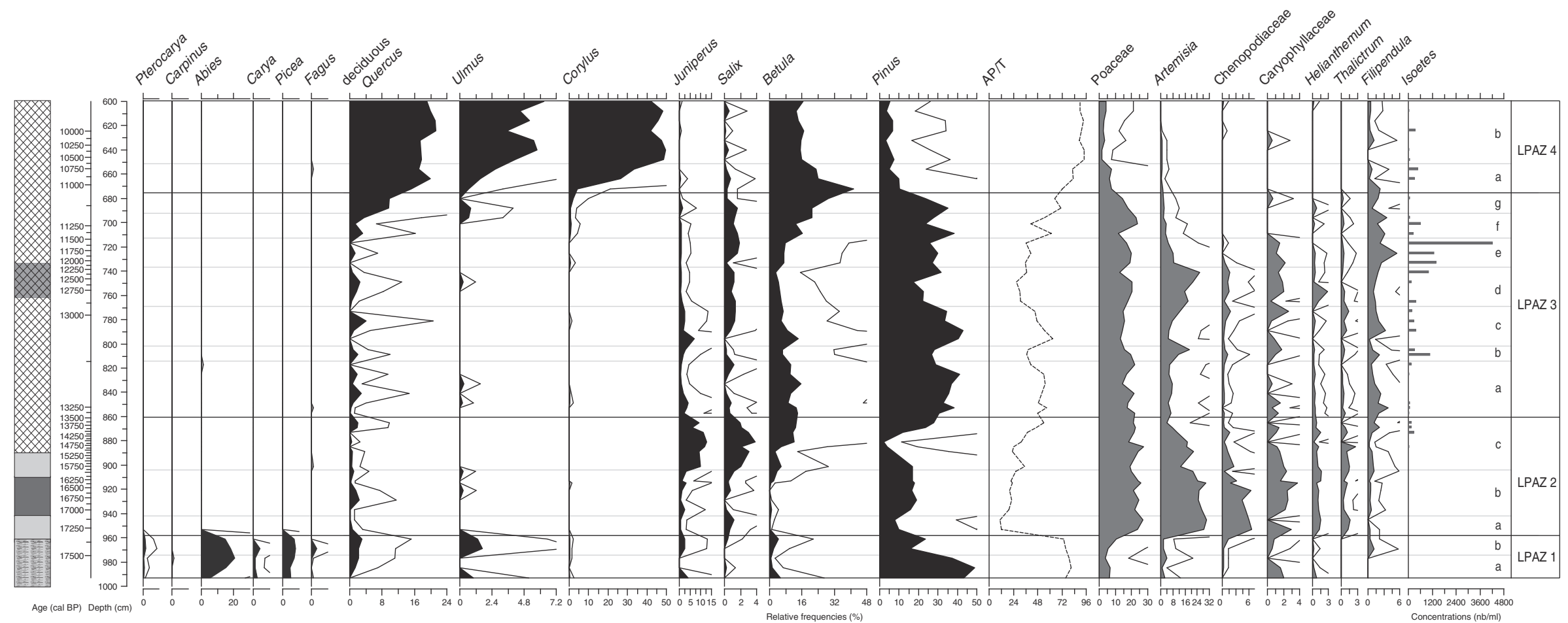

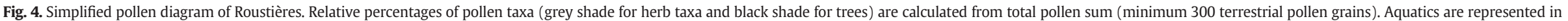
concentrations (nb/ml). $5 \times$ exaggeration curves are shown as lines; LPAZ: local pollen assemblage zones based on depth-constrained cluster analysis (CONISS). 
Table 2

Summary description of local pollen assemblages zones (LPAZ) and beetle assemblage zones (BAZ)

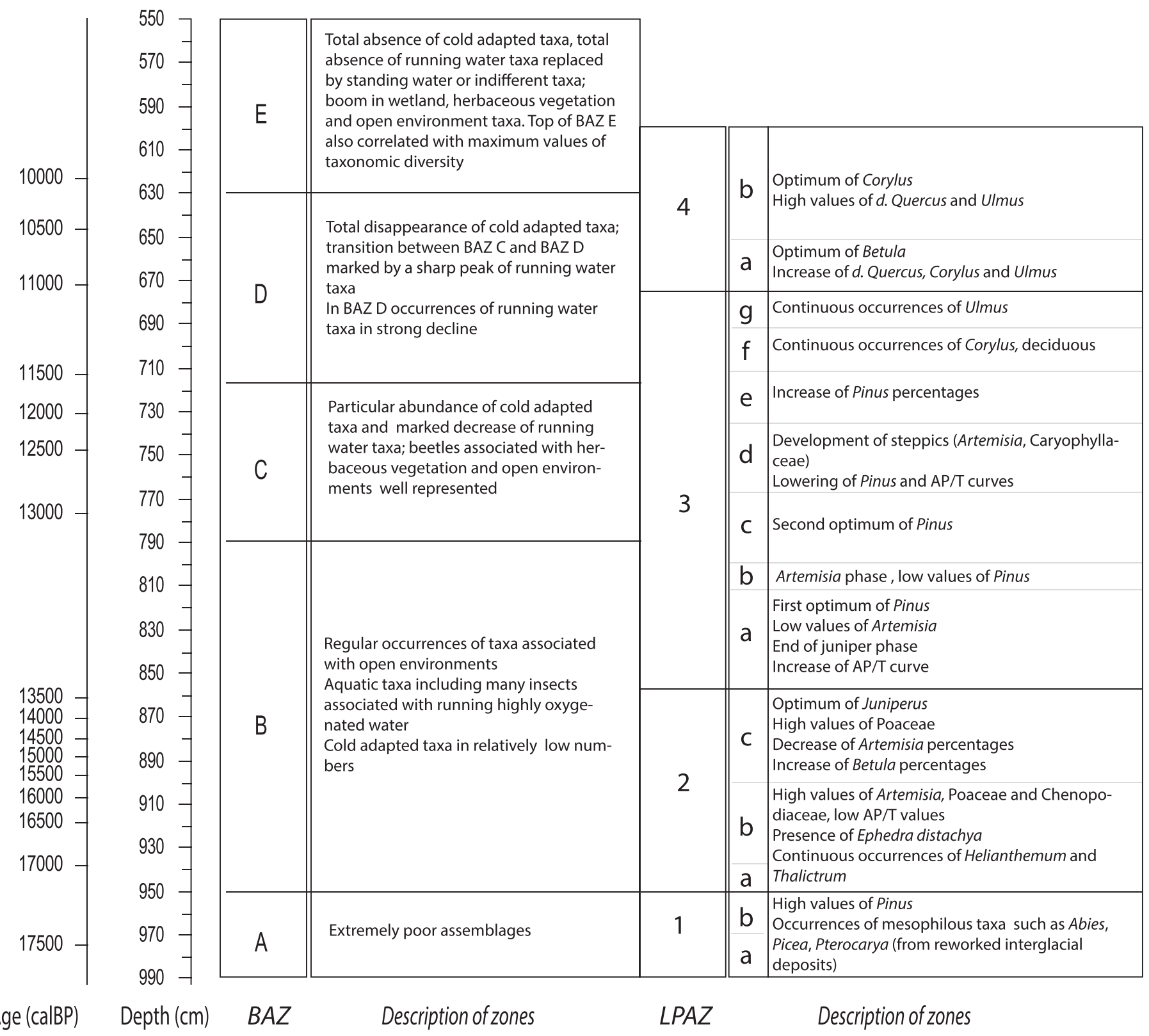

\subsubsection{LPAZ 2c: Bølling}

This zone is marked by a lowering of the percentage of steppic herbs, while the area was progressively recolonized by shrubs such as Juniperus and Salix, as it is classically recorded at the onset of the Lateglacial Interstadial in Massif Central (Beaulieu et al., 1985, 1988). At the same time, Pinus reaches its lowest percentages. This phase was triggered by the general warming observed at the global scale corresponding to the Gl-1e documented in Greenland isotopic records (Rasmussen et al., 2014) which is also marked by an increase in lacustrine productivity at Brameloup, with the beginning of gyttja deposits. This episode of expansion of Juniperus (with Salix) is estimated at around 14,884-15,148 cal. BP by the age-depth model ( 2 sigmas interval). It could mean that this event slightly predates the accepted age for the beginning of the LGI, i.e. 14,700 cal. BP, and that the Bølling chronozone would begin in the middle of LPAZ 2c, with a transitory increase of Betula. At La Chaumette, distant of $2 \mathrm{~km}$ from Les Roustières, the expansion of Juniperus is dated between 15,426 \pm 657 and
$14,633 \pm 592$, which is, in spite of the large error, coherent with the ages obtained at Les Roustières.

Curiously, in the older diagram from Beaulieu et al. (1985) the Bølling is recorded as bipartite with an optimum of Juniperus, followed by a stable phase with juniper and birch, which is not recorded in our profile. This could suggest a hiatus in our pollen record, with a resulting "cut off' of the juniper phase classically assigned to the onset of the Bølling.

\subsubsection{LPAZ 3a-LPAZ 3b-LPAZ 3c: Allerød}

After the juniper phase during the Bølling, Pinus became predominant while Artemisia reached its lowest percentages (LPAZ 3a) for the Lateglacial period. Filipendula, already present since the Bølling is more abundant during zones LPAZ $3 a$ and 3b, suggesting the establishment of a belt of tall herbs surrounding the lake and/or along the streams which feed it. The regular occurrences of deciduous Quercus throughout the LGI could indicate that oak woodlands were developing at lower altitudes. As it was already proposed by pioneer studies 
Insects from Roustières. Coleopteran taxonomy and systematic order follow Lucht (1987) as closely as possible.

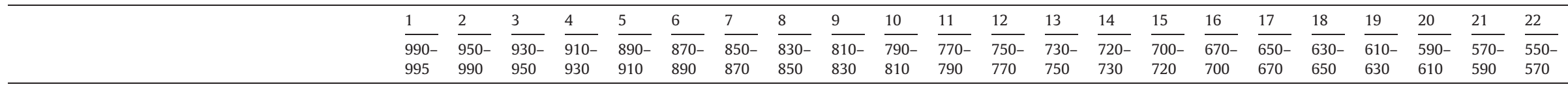

\section{COLEOPTERA
Carabidae}

Cicindela campestris $\mathrm{L}$.

Notiophilus pusillus Wtrh.

Notiophilus cf. aquaticus (L.)

Bembidion (Princidium) bipunctatum (L.)

Bembidion (Testediolum) sp.

Bembidion sp.

Harpalus sp.

Pterostichus (Argutor) diligens (Sturm)

Agonum (Europhilus) thoreyi Dej.

Amara (Percosia) equestris (Duft.)

Amara sp.

Odacantha melanura (L.)

G. sp.

Haliplidae

Haliplus confinis Steph.

Haliplus fulvus (F.)

Dytiscidae

Hyphydrus ovatus (L.)

Coelambus cf. novemlineatus (Steph.)

Hygrotus inaequalis ( $\mathrm{F}$ )

Hydroporus scalesianus Steph.

Hydroporus cf palustris (L)

Hydroporus spp.

Potamonectes griseostriatus (Geer)

Potamonectes depressus (F.) ( elegans (Panz)

Noterus crassicornis (Müll.)

Agabus bipustulatus (L)

Agabus arcticus (Payk.)

Agabus spp.

Ilybius sp.

Rhanthus sp.

Colymbetes fuscus (L.)

Graphoderus sp.

Acilius canaliculatus (Nicol.)

Dytiscus sp.

Gyrinidae

Gyrinus sp.

Hydraenidae

Hydraenidae

Hydraena sp.

Limnebius cf. aluta Bedel

Limnebius spp.

Hydrochus sp.

Helophorus schmidti Villa

Helophorus glacialis Villa

Helophorus cf. griseus Hbst.

Helophorus spp.

Hydrophilidae

Coelostoma orbiculare (F.)

Hydrobius fuscipes (L.)

Anacaena sp.

h
h
h
c
c
u
u
wet
wet
u
u
wet
u
w
w
w
w
w
w
w
w
w
w-c
w
w
w
w-c
w
w
w
w
w
w
w
w
w
w
w
w
w
w
w-c
c
w
w
w
w
w


Catops sp.

Philorinum sordidum (Steph.)

Philorinum sordidum (Steph.)

Olophrum cf. fuscum (Grav.)
Olophrum sp.

Eucnecosum brachypterum (Grav.)

Acidota cruentata (Mannh.)

esteva longelytrata (Goeze)

Platysthetus sp.

Stenus spp.

Pseudomedon obscurellus (Er.)

Lathrobium terminatum Grav.

Lathrobium rufipenne Gyll.

Lathrobium sp.

Cryptobium fracticorne (Payk.)

Erichsonius cinerascens (Grav.)

Quedius spp.

Quedius/Philonthus spp.

Acylophorus glaberrimus (Hbst.)

Mycetoporus sp.

Tachyporus hypnorum (F.)

Tachyporus sp.

Tachinus rufipes (Geer)

Tachinus elongatus Gyll.

Tachinus sp.

Gymmusa brevicollis (Payk.)

Lomechusa strumosa ( $\mathrm{F}$.)

Aleocharinae indet.

Staphylinidae indet.

Pselaphidae

Bryaxis sp.

Pselaphus heisei Hbst.

Cantharidae

Cantharis sp.

Charopus sp.

Charopus sp.

Haplocnemus s

Haplocnem

Dasytes sp.

Dolichosoma lineare (Rossi)

Elateridae

Ampedus sp.

Adrastus sp.

Anostirus cf. gracilicollis (Stierl.)

Elateridae indet.

Helodidae

Scirtes haemisphaericus (L.)

Helodidae indet. 
Table 3 (continued)

Table 3 (continued)

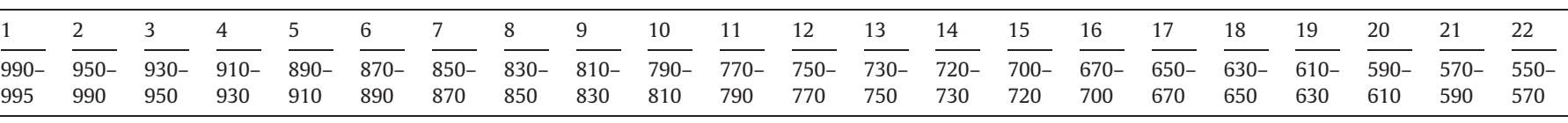

Esolus parallelipipedus (Müll.)

Oulimnius tuberculatus (Müll.)

Oulimnius troglodytes (Gyll.)

Oulimnius sp.

Limnius volckmari (Panz.)

Limnius cf. opacus Müll.

Normandia nitens (Müll.)

Byrrhidae

?Cytilus auricomus (Duft.)

Byrrhidae indet.

Nitidulidae

Meligethes sp.

Lathridiidae

Corticariini indet.

Coccinellidae

Hippodamia tredecimpunctata (L.)

Anisosticta novemdecimpunctata (L.)

Coccinellidae indet.

Anthicidae

Anthicus sp.

Alleculidae

somira sp.

Omophlus cf. rufitarsis (Leske)

Scarabaeidae

Aphodius haemorrhoidalis (L.)

Aphodius mixtus Villa

Aphodius spp.

Serica brunnea (L.)

Amphimallon/Rhizotrogus sp.

Cerambycidae

Leiopus nebulosus (L.)

Chrysomelidae

Macroplea appendiculata (Panz)

Donacia dentata Hoppe

Donacia spp.

Donacia/Plateumaris spp.

Cryptocephalus sp.

Galerucella luteola (Müll.)

Phyllotreta procera (Redt)

\begin{tabular}{|c|c|c|c|c|c|c|c|c|c|c|c|c|c|c|c|c|c|c|c|c|c|}
\hline - & - & - & 3 & - & - & - & 1 & - & - & - & - & - & - & - & - & - & - & - & - & - & - \\
\hline - & - & - & - & - & - & 1 & - & - & - & - & - & - & - & - & - & - & - & - & - & - & - \\
\hline - & - & - & - & - & - & - & - & - & - & - & - & - & - & - & 2 & - & - & - & - & - & - \\
\hline - & - & - & - & - & - & - & - & - & - & 1 & - & - & 1 & 1 & - & - & - & - & - & - & - \\
\hline - & - & - & 1 & - & - & - & 1 & - & - & 1 & - & - & 1 & - & - & - & - & - & - & - & - \\
\hline - & - & - & - & - & 2 & 2 & 1 & 2 & 1 & - & - & - & 3 & 4 & - & - & - & - & - & - & - \\
\hline - & - & - & - & - & - & 1 & - & - & - & - & - & 1 & - & 1 & - & - & - & - & - & - & - \\
\hline - & - & - & - & - & - & - & - & - & - & - & - & - & - & - & - & - & - & - & - & - & - \\
\hline - & - & - & - & - & - & - & - & - & - & - & - & - & - & - & - & - & - & - & 1 & - & - \\
\hline - & - & - & - & - & - & - & - & - & - & - & - & - & - & - & - & - & - & - & - & - & 1 \\
\hline - & - & - & - & - & - & - & - & - & - & - & - & - & - & - & - & - & - & - & - & - & - \\
\hline - & - & - & - & 1 & - & - & - & - & - & - & - & - & - & 1 & - & - & - & - & - & - & - \\
\hline - & - & - & - & - & - & - & - & - & - & - & - & - & - & - & - & - & - & - & - & - & - \\
\hline - & - & - & - & - & 1 & - & - & - & - & - & - & - & - & - & - & - & - & - & - & - & - \\
\hline - & - & - & - & - & - & - & - & - & - & - & - & - & - & - & - & - & - & - & - & - & - \\
\hline - & - & - & - & - & - & - & - & - & - & 1 & - & - & - & - & - & - & - & - & - & - & - \\
\hline - & - & - & - & - & - & - & - & - & - & - & - & - & - & - & - & - & - & - & 1 & - & - \\
\hline - & - & - & - & - & - & - & - & - & - & - & - & - & - & - & - & - & - & - & 1 & - & - \\
\hline - & - & - & - & - & - & - & - & - & - & - & - & - & - & - & - & - & - & - & - & - & - \\
\hline - & - & 1 & - & - & - & - & - & - & - & - & 1 & 1 & - & - & - & - & - & - & - & - & - \\
\hline - & - & - & - & - & - & - & - & - & - & - & - & - & - & - & - & - & - & - & - & - & - \\
\hline - & - & - & - & 1 & - & - & - & - & 1 & - & - & - & - & 2 & - & - & - & - & - & - & - \\
\hline - & - & - & - & - & - & - & - & - & - & - & - & - & 1 & 1 & 1 & - & - & - & - & - & - \\
\hline - & - & - & - & - & - & - & - & - & - & - & - & - & - & - & - & - & - & - & - & - & - \\
\hline - & - & - & - & - & - & - & - & - & - & - & - & - & - & - & - & 1 & - & - & - & - & - \\
\hline - & - & - & - & - & - & - & - & - & 1 & - & - & - & - & - & - & - & - & - & - & - & - \\
\hline - & - & - & - & - & 2 & 2 & 1 & 1 & - & 2 & 3 & 4 & 2 & - & - & - & - & - & - & - & - \\
\hline - & - & 1 & 1 & 1 & - & 1 & - & - & - & - & - & - & 2 & 2 & - & - & - & - & - & - & - \\
\hline - & - & - & - & - & - & - & - & - & - & - & - & - & - & 1 & - & - & - & - & - & - & - \\
\hline - & - & - & - & 1 & - & - & - & - & - & - & - & - & - & - & - & - & - & - & - & - & - \\
\hline - & - & - & - & - & - & - & - & - & - & - & - & - & - & - & - & - & - & - & - & - & - \\
\hline - & - & - & - & - & - & - & - & - & - & - & - & - & - & - & - & - & 1 & - & - & - & - \\
\hline - & - & - & - & - & - & - & - & - & - & - & - & - & - & - & - & - & - & - & - & - & - \\
\hline - & - & - & 1 & - & 1 & 1 & - & 2 & 1 & - & 1 & - & - & 2 & 5 & 5 & 7 & 4 & - & - & - \\
\hline - & - & - & - & - & - & - & - & - & - & - & - & - & - & - & - & - & - & 2 & - & - & - \\
\hline - & - & - & - & - & - & - & - & - & - & - & - & - & - & - & - & 1 & 1 & 1 & 1 & - & - \\
\hline - & - & - & - & - & - & - & - & - & - & - & - & - & - & - & - & - & - & - & - & - & 1 \\
\hline - & - & - & - & - & - & - & - & - & - & - & - & - & - & - & - & - & - & 1 & - & - & - \\
\hline - & - & - & - & - & - & - & - & - & - & - & - & - & - & - & - & 1 & - & 2 & - & - & - \\
\hline- & - & - & - & - & - & - & - & - & 1 & - & - & - & - & - & - & - & - & - & - & - & - \\
\hline
\end{tabular}


Longitarsus holsaticus (L.)

Longitarsus sp.

Altica sp.

Crepidodera sp.

Chaetocnema sahlbergi (Gyll.)

Chaetocnema sp.

Alticinae indet.

Hispella atra (L.)

Bruchus/Bruchidius sp.

Curculionidae

Apion sp.

Otiorhynchus sp.

Phyllobius cf. argentatus (L.)

Phyllobius/Polydrusus spp.

Bagous sp.

Dorytomus sp.

Limnobaris pilistriata (Steph.)

Eubrychius velutus (Beck.)

Rhinoncus sp.

Rhynchaenus

(

Rhamphus sp.

Curculionidae indet.

Hebrus ruficeps (Thoms.)

Gerris sp.

Chartoscirta cocksii (Curtis)/elegantula (Fallén)

Saldidae indet.

Hemiptera indet.

MEGALOPTERA

Sialis sp.

RHAPHIDIOPTERA

Raphidia sp.

HYMENOPTERA

Myrmica sp.

Raptiformica/Coptoformica sp.

Formica sp.

Camponotus sp.

Formicidae indet.

TRICHOPTERA

(Time

Trichoptera indet.
DIPTERA

Bibionidae indet.

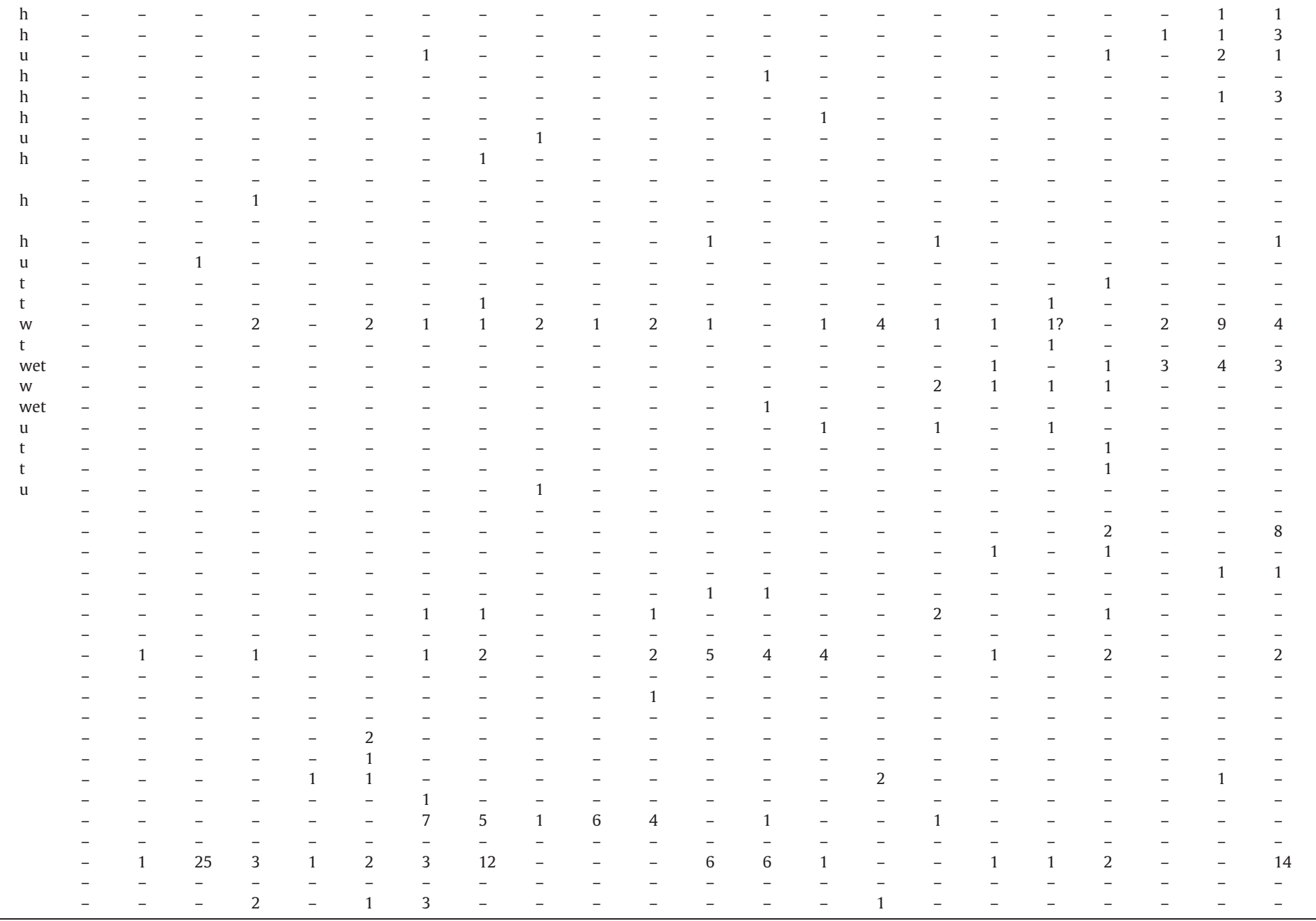

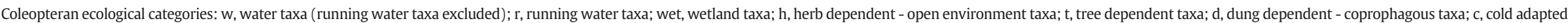
taxa; u, unclassified taxa (e.g., eurytopic taxa, or identified at a high taxonomic level). 


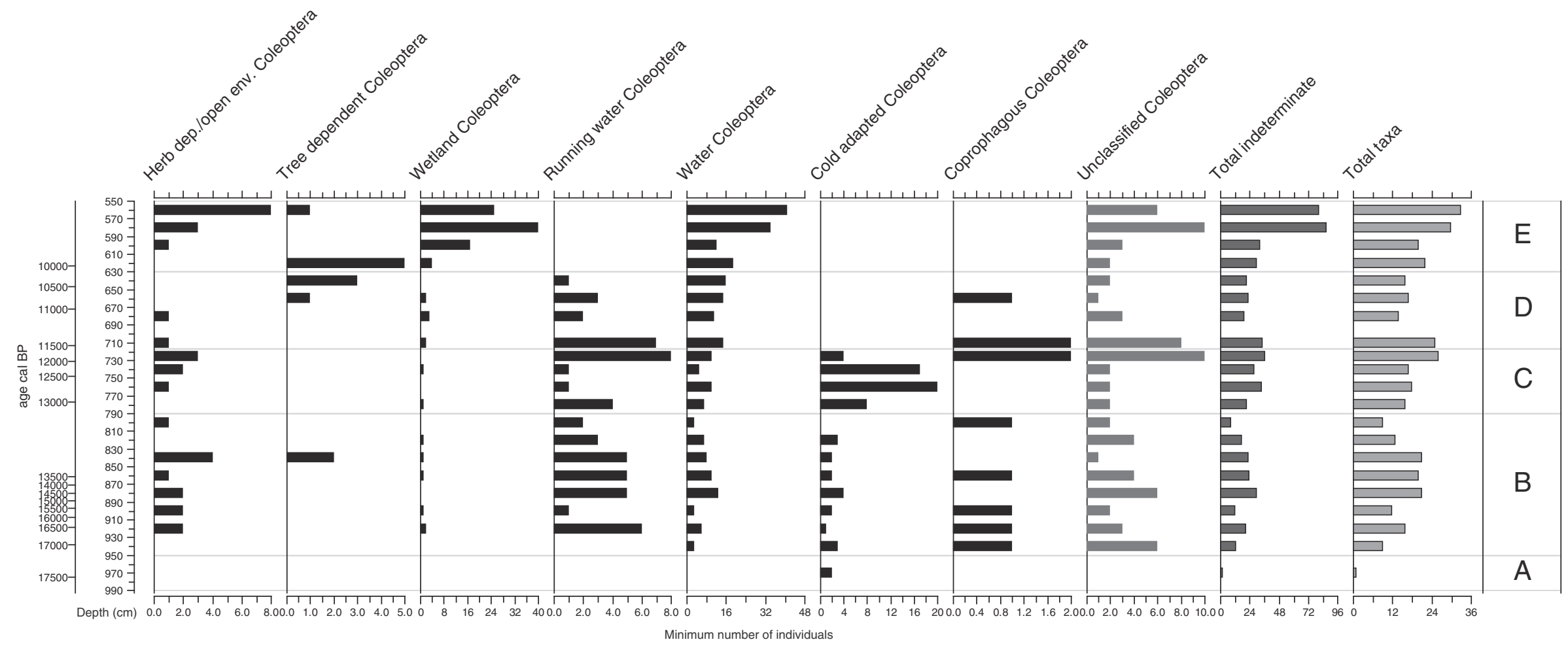

Fig. 5. Simplified beetle diagram of Roustières with the main ecological categories. Beetle assemblage zones A to E are described in the text. 
(Beaulieu et al., 1982, 1984; Reille and Beaulieu, 1988), the warming initiated during the Bølling may have contributed to an early expansion of deciduous Quercus from glacial refugia in the lower part of the Massif Central but oak was certainly absent from the Aubrac plateau, considering the low values of Quercus percentages during the whole Lateglacial: this point will be further discussed in the light of beetle data which provides information about the local environment. LPAZ 3b is marked by a transitory decline of the Pinus curve associated with a peak of Artemisia. This transient phase may be attributed to an intra-Allerød cold oscillation. However, the possibility of a rapid climate shift will be debated latter in the light of both age-depth model and multi-proxy comparison.

\subsubsection{LPAZ 3d-LPAZ 3e: Younger Dryas}

From ca 12,700-12,900 cal. BP according to the age-depth model, a rapid reversal in the vegetation dynamics marks the beginning of the Younger Dryas (LPAZ 3d): steppic herbs (Artemisia, Helianthemum, Chenopodiaceae, Caryophyllaceae, Poaceae) reach a second optimum while percentages of Pinus and Betula are significantly low. The Younger Dryas is generally poorly developed in pollen records from Aubrac, except at Roustières (Brameloup in Beaulieu et al., 1985) and Bonnecombe (Beaulieu et al., 1985). The sediment is composed of clayey gyttja which suggest a resumption of erosion in the catchment area together with a possible reduction of biogenic sedimentation undoubtedly linked to the Younger Dryas cold episode (Gs1). LPAZ 3e is marked by a return of Pinus and Betula while percentages of steppic herbs lower rapidly. This zone characterizes the end of Younger Dryas, with a progressive return of a more temperate climate.

\subsubsection{LPAZ 3f-LPAZ 4b: Early Holocene}

The global warming of the beginning of the Holocene is marked at Roustières by a complex succession of mesophilous trees in three steps: 1) a rapid and transitory optimum of Betula, with the persistence of Pinus (LPAZ 3f-LPAZ 4a), followed by 2) the development of deciduous Quercus (LPAZ 4a-LPAZ 4b), and finally 3) from ca 10,70010,500 cal. BP, the concomitant expansion of Ulmus and Corylus (LPAZ $4 \mathrm{~b})$, corresponding to the Preboreal/Boreal. Such a succession is characteristic of the beginning of the Holocene in Massif Central and French Pyrénées with this early expansion of Quercus, while in western Alps Corylus played the role of pioneer in the postglacial vegetation recolonization (Finsinger et al., 2006). According to the age-depth model, the expansion of these deciduous trees happened in less than six centuries, which again supports the evidence of regional refugia, especially for deciduous Quercus.

\subsection{Coleoptera}

In total, 149 taxa of Coleoptera were identified, of which 75 (exactly $50 \%$ ) were identified to species or species-group level (Table 3). Other insect orders include Hemiptera, Megaloptera, Raphidioptera, Hymenoptera (Formicidae), Trichoptera, and Diptera, however their occurrence in relatively low numbers lead us to focus this work on the Coleoptera (beetles). In order to make the interpretation of the coleopteran record easier, the taxa were grouped according to their main ecological requirements (Table 3, Fig. 5). The changes affecting the main ecological categories enable to divide the sequence into 5 beetle assemblage zones (BAZ).

\subsubsection{Beetle assemblage zone A}

This zone is restricted to 2 samples only and has an extremely poor insect content: one sample is sterile, the other one contains only the cold dependent Helophorus glacialis, among the Coleoptera taxa. This scarcity in fossils may be explained by taphonomic factors, or by an extremely harsh environment that can be compared with a polar desert.

\subsubsection{Beetle assemblage zone $B$}

BAZ B is marked by regular occurrences of taxa associated with open environments, aquatic taxa including many insects associated with running highly oxygenated water, and cold adapted taxa in relatively low numbers.

4.3.2.1. Aquatic insect assemblages. Bagous and Haemonia appendiculata are two beetle taxa associated with aquatic plants, they are both present in BAZ B but occur in most of the samples throughout the sequence (from BAZ B to BAZ E). These taxa are clearly local, they suggest a rich aquatic vegetation with abundant Potamogeton and Myriophyllum spicatum (host-plants for $H$. appendiculata). The weevil genus Bagous comprises many species associated with various aquatic plant taxa.

From BAZ B upwards two aquatic Coleoptera are almost constantly present: Haliplus fulvus and Potamonectes depressus/elegans. Haliplus fulvus is found mainly "in clear, clean bodies of stagnant, and especially in the north, in slowly running water; particularly found in oligoproductive, slightly acid lakes with growth of characeans" (Holmen, 1987). Potamonectes depressus/elegans occurs in lakes and large bodies of running water, most often on hard bottoms with little or no vegetation (Nilsson and Holmen, 1995).

Running water aquatic Coleoptera are abundant, both taxa and individuals, with Elmis cf. aenea, Esolus parallelepipedus, Oulimnius tuberculatus, Limnius volckmari, L. opacus, and Normandia nitens. These water beetles are associated with running water characterized by a high oxygen content, they are uncommon or absent in lakes. Potamonectes griseostriatus is a boreo alpine species, indicating cold climatic conditions.

4.3.2.2. Terrestrial insect assemblages. Beetle assemblages from BAZ B contain many terrestrial cold adapted insects. One of the most significant Coleoptera is probably Helophorus glacialis. This is in fact a semiterrestrial species since it lives in the mud at the margin of melting snow, in mountains above $2000 \mathrm{~m}$ in the south of its area, and at sea level in Fennoscandia. The definitively terrestrial Bembidion bipunctatum shows similar ecological requirements, it is common today around snow patches in the mountains of the palaearctic region (Marggi, 1992). The rove-beetle Eucnecosum brachypterum is another widespread species in northern Europe and northern Scandinavia but with a very restricted range in central and southern Europe. It exists in the Alps but is not reported from France (Zanetti, 1987). This staphylinid is not associated with snow patches but is found in rotten vegetal debris in cold regions. Aphodius mixtus is today a French endemic Scarabaeid restricted to high altitude grasslands in the Alps, Massif Central and Pyrénées. Most of its distribution area is above $1700 \mathrm{~m}$ and 50\% of its localities are above $2000 \mathrm{~m}$. Contrary to most of the other members of the genus Aphodius, A. mixtus is not a true dung beetle since its larvae are found in rotten vegetal matter that accumulates on grounds with a dense cover of Poaceae in alpine grasslands (Ponel et al., 1995; Lumaret et al., 1996). Tachinus elongatus, Notiophilus pusillus and Amara equestris are also rather alticolous in the south of their range, and associated with open landscapes.

Among phytophagous species, several beetles are also ecologically very significant, it is the case of Hispella atra and Dolichosoma lineare, strictly associated with Poaceae in pastures and grasslands. Charopus is a genera associated with steppic environments. The small staphylinid Philorinum sordidum is a floricolous species widespread in Europe and associated with flowers of shrubby and ligneous Fabaceae such as brooms (Cytisus, Genista, Ulex) (Zanetti, 1987). The members of the family Bruchidae (represented by Bruchus/Bruchidius) are also associated with Fabaceae on which their larvae develop inside seeds.

4.3.2.3. Palaeoecological interpretation. The 8 assemblages that constitute BAZ B provide a clear and coherent picture of the palaeoenvironment. Helophorus glacialis and Aphodius mixtus suggest that a cold climate prevailed at that time, in a totally open landscape (but it is possible 
that isolated trees such as Salix or Betula were present near the depositional site). However, the relatively low numbers and the episodic occurrences of both Helophorus glacialis and Aphodius mixtus indicate that temperature and palaeoenvironmental conditions were close to the limit of their ecological requirements; their populations were probably localized on the top and northern slopes of the surrounding hills, and expanded downwards from their strongholds to reach the margin of the palaeolake as their temperature threshold was crossed. This hypothesis is supported by the sustained occurrence of running water Coleoptera, certainly brought into the site by small tributaries flowing down from the surrounding hills (as it is still the case today), indicating that temperature was not low enough to permanently freeze the rivulet system. It is possible that isolated specimens of $H$. glacialis and A. mixtus were also carried into the lake with water streaming, along with running water beetles.

\subsubsection{Beetle assemblage zone $C$}

This BAZ is clearly indicated by the occurrence of two important events: a particular abundance of cold adapted taxa and a marked decrease of running water taxa; beetles associated with herbaceous vegetation and open environments are also well represented.

4.3.3.1. Aquatic insect assemblages. Potamonectes griseostriatus is still present but two other Dytiscids appear: Agabus bipustulatus and Agabus arcticus. The former is an eurytopic and eurythermic species with a wide latitudinal and altitudinal expansion that provides few palaeoenvironmental information, however the latter is a very significant insect from a palaeoclimatic point of view: Agabus arcticus is present today in Ireland and the Scottish Highlands and over much of Scandinavia and is a very cold adapted circumpolar species. "It prefers permanent water-bodies such as lakes and larger bodies of running water" (Nilsson and Holmen, 1995). This taxon is present in BAZ C only. The other component of the aquatic fauna, the running water beetle category, is strongly declining in the middle of BAZ C, then rises again at the limit between BAZ C and BAZ D.

4.3.3.2. Terrestrial insect assemblages. Many "cold" taxa already observed in BAZ B are still present in BAZ C. This is the case for Bembidion bipunctatum, Helophorus glacialis, Aphodius mixtus. Eucnecosum brachypterum found as only one isolated specimen in $\mathrm{BAZ} \mathrm{B} /$ sample $890-910$ is now found in every sample from BAZ C. Dolichosoma lineare, a Coleoptera associated with grassland and steppic environments was already present in BAZ B. Some other taxa are found for the first time in the sequence: Cicindela campestris, Notiophilus cf. aquaticus, Bembidion (s.g. Testediolum) sp. These three species are associated with open landscapes, especially Cicindela campestris, the well-known tiger-beetle, but Testediolum is another ground beetle typical of melting snow patches, with an ecology similar with that of Bembidion bipunctatum already found in BAZ B. Among the semi terrestrial taxa, Helophorus glacialis is particularly abundant, but is now present with another representative of the same genus, Helophorus schmidti, which has similar ecological requirements. Finally, the main characteristic of BAZ C is the high abundance of two strongly cold adapted taxa, Helophorus glacialis and Aphodius mixtus.

4.3.3.3. Palaeoecological interpretation. At that time the environment around the palaeolake was similar to an arctic steppe or to alpine environments above $2000 \mathrm{~m}$. Snow patches were present close to the lake, and persisted during much of summer. The increased cold conditions are clearly indicated by the high number of taxa and individuals of arctic-alpine insects. A secondary effect of the strong cooling of the climate is a change in the hydrological regime, as indicated by the marked decrease of the running water community, a consequence of a freezing of small rivulets feeding the lake, and/or temperatures too low for the running water beetles.

\subsubsection{Beetle assemblage zone $D$}

BAZ D corresponds to the total and definitive disappearance of cold adapted taxa. The transition between BAZ C and BAZ D is marked by a sharp and brief peak of running water taxa, in BAZ D the occurrences of this ecological category are strongly declining.

4.3.4.1. Aquatic insect assemblages. The main feature of the aquatic component is the strong peak of running water taxa straddling the boundary between BAZ C and BAZ D, with Elmis cf. aenea, Oulimnius sp., Limnius volckmari, Limnius cf. opacus, Normandia nitens. In the rest of BAZ D, running water taxa are still present but in lower number. Many water beetles appears for the first time in the sequence: Haliplus confinis, Hyphydrus ovatus, Hygrotus inaequalis, Hydroporus cf. palustris, Graphoderus sp., Gyrinus sp., typical of standing water, or associated with shallow water bodies with a dense growth of aquatic vegetation. This is also the case for Noterus crassicornis, Enochrus sp., and Berosus signaticollis. Some other water beetles are associated with transitional environments and may be considered as semi terrestrial, such as Coelostoma orbiculare or Chaetarthria sp. that live in plant debris at the margin of standing water. The presence of Myriophyllum, already revealed by the oligophagous Chrysomelidae Haemonia appendiculata present throughout the sequence, is confirmed by the amphibious weevil Eubrychius velutus, another beetle associated with this aquatic plant genus. BAZ D is also marked by the disappearance of Potamonectes depressus/elegans, known to prefer water bodies with little or no vegetation.

4.3.4.2. Terrestrial insect assemblages. In BAZ D the cold adapted taxa that dominated the 4 assemblages in BAZC are suddenly eradicated from the sequence and never reappear. Conversely, many terrestrial insects are found for the first time: the staphylinids Acidota cruentata and Lesteva longoelytrata are associated with damp grounds covered with rotten plant debris were they feed on small insects such as Collembola. Another staphylinid, Lomechusa strumosa, has a quite unusual biology since it is a myrmecophilous species. It is a xerophilous insect usually found under stones and in Calluna litter, often associated with Formica sanguinea nests. Interestingly, two specimens of Formica were also counted in the same sample 700-720.

The Scarabeid Serica brunnea feeds at the roots of various plants during its larval stages. It is today found in conifer forests, on sandy grounds with herbaceous vegetation (Paulian and Baraud, 1982).

Leiopus nebulosus is a true tree-dependent insect, a xylophagous longhorn species that feeds during its larval stages on dead wood, on various non coniferous tree species (Villiers, 1978). BAZ D is also marked by the first record of the monophagous Galerucella luteola, the elm leaf beetle which feeds exclusively upon leaves of Ulmus campestris. Another tree dependent Coleoptera is found in this zone: the weevil Dorytomus sp., which belongs to a genus associated with Populus and Salix exclusively. The weevil Limnobaris pilistriata, a phytophagous species that feeds on various Juncaceae and Cyperaceae (Scirpus, Carex, Cladium, etc.), indicates that the lake was surrounded by a hygrophilous vegetation growing on marshy grounds.

The transition BAZ C/BAZ D is also marked by a temporary but strong increase in taxonomic diversity and number of individuals. Such abundance will only be surpassed in the two uppermost samples of the sequence, in BAZ E.

4.3.4.3. Palaeoecological interpretation. The transition between BAZ C and BAZ D corresponds clearly to the turning point between two eras within the beetle sequence. A major ecological change takes place at that time, obviously in response to a major climatic change.

We see the complete replacement of the cold fauna by temperate elements, an event certainly induced by a rapid climate warming. This warming is associated with a strong increase in water flow and brook energy, as indicated by the sharp peak of running water beetles. This 
event could be correlated with a generalized snow patch melting in the area, in response to the rapid warming.

The zone D corresponds to the first records of several true tree dependent Coleoptera, especially the elm leaf beetle, which suggests that Ulmus was spreading around the lake at that time. Other tree dependent taxa, such as Dorytomus, are probably associated with the riverine arboreal or shrubby vegetation such as willows, growing on the site itself.

The replacement of water beetles such as Potamonectes depressus/ elegans (a taxon associated with lakes devoid of vegetation) by water beetles preferring shallow water with helophytic vegetation, along with the appearance of Limnobaris associated with Juncaceae and Cyperaceae, suggest that the lake is now progressively infilled by sediments and that a diversity of wetland plants is gradually choking the water surface. However the wetland Coleoptera category remains very low, suggesting that the development of a marshy semi terrestrial environment with a mosaic of emerging ground and pools remained restricted to a narrow area, probably at the margin of the lake.

\subsubsection{Beetle assemblage zone E}

This uppermost BAZ is indicated again by a total absence of cold adapted taxa, along with a total absence of running water taxa which are replaced by standing water or indifferent aquatic taxa, a boom in wetland taxa, and in taxa associated with herbaceous vegetation and open environments. The top of BAZ E is also correlated with maximum values of taxonomic diversity.

4.3.5.1. Aquatic insect assemblages. A striking feature here is the total absence of running water taxa in this zone, suggesting a marked change in the hydrological regime. They are replaced by a diversified community of predominantly standing water beetles, a category that reaches its maximum in this zone and especially in the uppermost sample (550570).

Many taxa from BAZ E were already identified in previous samples: Hygrotus inaequalis, Noterus crassicornis, Agabus sp., Colymbetes fuscus, Graphoderus sp., Dytiscus sp., Ochthebius sp., but some others appear for the first time, for example Ilybius sp., and the ecologically interesting Hydroporus scalesianus. A distinctive biological feature of this very small uncommon Hydroporus is that it is able to live in water bodies almost totally choked with Sphagnum mosses. Among Hydrophilid water beetles, Hydrochus and Limnebius cf. aluta are found for the first time, the latter being frequent and relatively abundant in BAZ E. The semi terrestrial Coelostoma orbiculare increases in this zone, with at least 11 individuals. This is also the case for Enochrus/Helochares, with 14 individuals in the last sample, and for Laccobius and Chaetarthria with respectively 6 and 5 individuals in the 2 last samples. All these insects are poor swimmers feeding upon aquatic plants in shallow standing water. They are particularly abundant in water bodies with very dense aquatic and helophytic vegetation or are semi terrestrial insects living in plant debris and mud at the limit between standing water and firm ground.

4.3.5.2. Terrestrial insect assemblages. BAZ E is also characterized by an expanding community of wetland Coleoptera, comprising several Carabidae (ground beetles), such as Pterostichus diligens, Agonum thoreyi, Odacantha melanura, and a rich association of hygrophilous Staphylinidae (rove beetles). Odacantha melanura lives inside hollow Phragmites stems where it preys upon small arthropods; it suggests that reeds were present around the lake. Pterostichus diligens and Agonum thoreyi are strongly hygrophilous predatory beetles usually found in mosses and wet plant debris in marshes and peat bogs. The Staphylinidae community includes Platysthetus sp., Stenus sp., Paederus sp., Pseudomedon obscurellus, Lathrobium terminatum, L. rufipenne, Cryptobium fracticorne, Erichsonius cinerascens, Acylophorus glaberrimus, Gymnusa brevicollis. All these insects are associated with damp ground, often densely vegetated with mosses (especially Sphagnum) and hygrophilous plants, and covered with a layer of rotten plant debris.
The family Helodidae is also well represented in the 4 assemblages from zone E, with at least 41 individuals in total. Apart from Scirtes haemisphaericus, most of the specimens were not identified to species or even genus level but it is likely that a vast majority corresponds to the genus Cyphon, very abundant in marshes with a dense herbaceous vegetation. In this family the larvae are apparently aquatic, whereas adults are found on tree foliage and on grasses. Anisosticta novemdecimpunctata, the water ladybird, is dependent on wetlands with rich helophytic vegetation, it is found on Phragmites, Typha, also on Iris, Sparganium, Juncus spp., Eleocharis palustris, etc. It feeds upon aphids especially Hyalopterus pruni. Longitarsus holsaticus is a widespread and easily recognisable flea-beetle associated with marshes, peat-bogs, marshy grasslands. It is oligophagous on Veronica beccabunga, V. scutellata, Gratiola officinalis, Pedicularis palustris (Doguet, 1994). Another flea-beetle, Chaetocnema sahlbergi, seems to be associated with Carex and Juncus, along with the weevil Limnobaris pilistriata, which was found as one isolated individual in BAZ D/sample 650-670 but now present in every sample in significant number. Donacia dentata is also recorded at the beginning of BAZ E (sample 610-630). It suggests that its host plant Sagittaria sagittifolia occurred at that time. The arrowhead is an aquatic plant of standing water bodies, widespread in Europe and beyond.

Tree dependent species from this zone include Rhynchaenus quercus, oligophagous on several Quercus species, and a click-beetle belonging to the genus Adrastus, a regular component of the insect community associated with riparian trees (willows, poplars, alders, etc.) where it is found on the foliage. Both are found in BAZ E as isolated specimens.

Among Heteroptera, Hebrus ruficeps is a very small bug preferring acid mires (Boyce, 2004), where it is found inside the thick layer of Sphagnum mosses; a biology that bears some resemblance with the water beetle Hydroporus scalesianus, also present in number in the same entomozone.

Considering the whole sequence, the uppermost assemblage (sample 550-570) is the taxonomically richest assemblage, with more than 30 taxa. This situation is obviously a consequence of the establishment of varied biotopes on the former lake, comprising probably: pools, mosses, Sphagnum hummocks, shrubby trees, dense and diversified hygrophilous vegetation, even forest at some distance from the site.

4.3.5.3. Palaeoecological interpretation. The overall impression that emerges from the assemblages BAZ $\mathrm{E}$ is that another major change takes place at that time, since almost every ecological category is affected by this event. But in contrast to the transition BAZC/BAZ D which was certainly driven by climate change, the transition BAZ D/BAZ $\mathrm{E}$ is now a consequence of the infilling of the lake and the colonization of recently emerged ground by a rich palustrine vegetation, with some trees (including probably willows), and, most importantly, with a diversified herbaceous flora. There is no evidence from insect data that such drastic ecological change could have been induced by climate change. As the cores have been taken in the deepest part of the depression, it is highly probable that a significant part of the site is now totally filled in with sediments and covered with hygrophilous plants including Sphagnum mosses, with comparatively less open water available.

There are also evidence for the presence of trees on the bank of the former lake and on the hills around the site, with Ulmus and Quercus. However the low representation of beetle taxa dependent on trees growing on firm and dry ground is certainly to be attributed to the size of the site and to the location of the corings. The presence of a true forest away from the depositional site cannot therefore be excluded, from beetle data and in the present state of knowledge, since Smith et al. (2010) suggest that small ponds do not collect insect taxa beyond approximately $1000 \mathrm{~m}$ radius from the sampling location (at least in lowland Britain). 


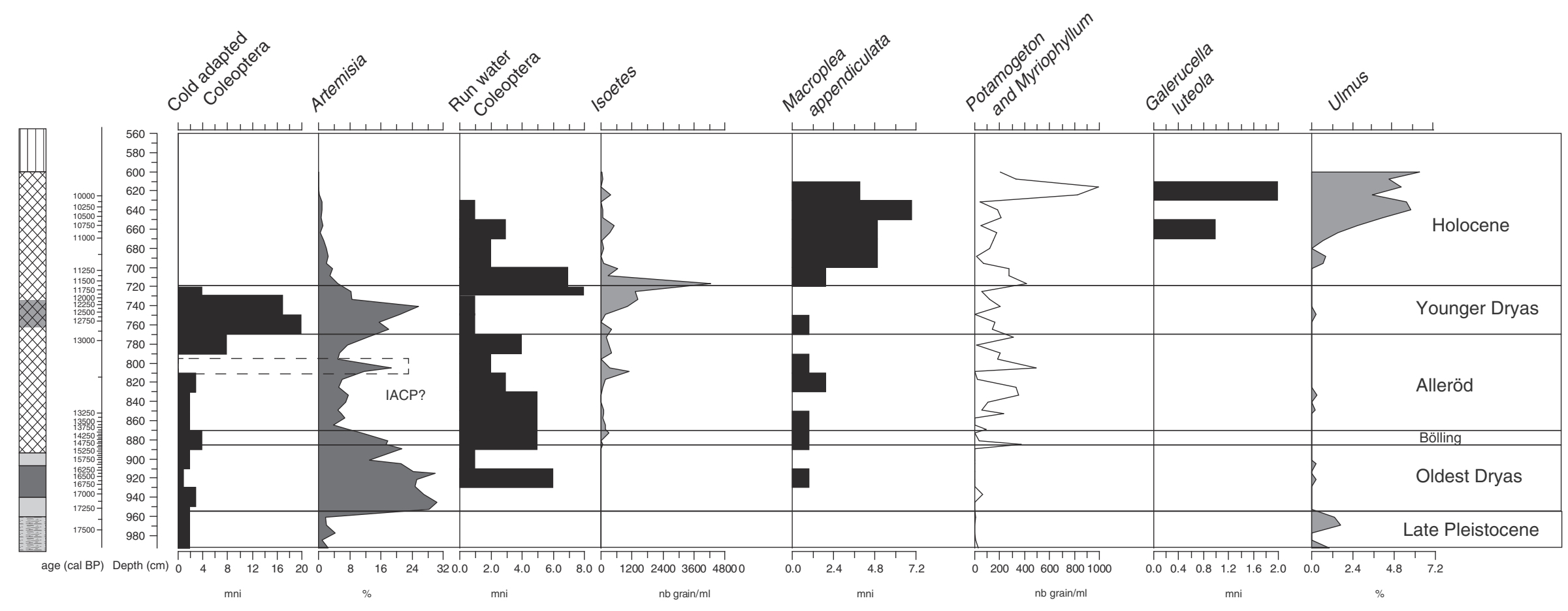

Fig. 6. Comparison diagram of selected plant and Coleoptera taxa (mni: minimum number of individuals). See Fig. 2 for the caption to lithology. 


\section{Discussion: beetles vs. pollen: a key for reconstructing past land- scape dynamics}

\subsection{A "treeless and cold" Lateglacial?}

The oldest beetle assemblages are marked by cold adapted Coleoptera (see BAZ A in Fig. 4) confirming that this period is contemporaneous of the ice cover retreat while vegetation cover is not yet developed. It must be also noticed that these cold-adapted beetles are recorded during the whole Lateglacial (Fig. 6). Evidence from coleopteran data suggests however that climate was not cold enough to freeze the activity of the small rivulets that fed the lake at that time and to eradicate the running water beetles. The Oldest Dryas cannot be characterized stratigraphically from beetle data only, but it is obviously restricted to the lowermost samples to judge from the radiometric and pollen data (Fig. 6). The boundary Oldest Dryas/LGI is marked by the significant abundance of running water Coleoptera. The local environment is therefore marked by the beginning of increased run off in response to the global warming of the LGI. However this warming was undoubtedly moderate, due to the relative altitude of the site and to the continental climate (which prevails still today in the Aubrac region, and generally on the Massif Central plateau).

Such harsh conditions did not allow any warm dependent fauna to establish on Aubrac plateau and the landscape remained treeless throughout the Interstadial, at least in the Roustières region. It must be noticed that the single occurrence of tree-dependent Coleoptera during the Allerød is contemporaneous with a first optimum of pine, while herb/open environment dependent beetles are well-represented: it must be assumed that during the whole Lateglacial, no forests or woodlands have been developing in the surroundings. The Betula percentages are rather low all along the zone suggesting patchy population not necessarily close to the lake. It is true also for Pinus which is poorly represented during the first half of the Lateglacial (LPAZ 1b to LPAZ 2c) but it is more abundant during the second part of the record (LPAZ 3a to LPAZ 3e), reaching about $50 \%$ of the pollen sum: the almost absence of tree-dependent insect during the Lateglacial suggests that high percentages of Pinus recorded during the Allerød are certainly due to regional pollen input from lowland areas. Scattered scrublands with Juniperus (a low pollen disperser) could be present in the watershed but absent close to the sampling area, which could explain dissimilarities in juniper pollen curves between sites.

The scarcity of tree dependent beetle throughout the LGI also confirms that wide open landscapes occupied the Aubrac Plateau at that time. An interesting comparison can be made with the regional Lateglacial insect site (Ponel and Coope, 1990; Ponel et al., 1991), la Taphanel (975 m altitude, compared with $1196 \mathrm{~m}$ at Roustières), located $70 \mathrm{~km}$ to the north west of Roustières, on the northern slopes of the Cantal Mts and Plomb du Cantal which culminates at 1855 m. Especially interesting in this insect sequence is the indication of a cold spell inside the Lateglacial Interstadial, in the form of occurrences of both Agabus arcticus and Helophorus glacialis. This episode was attributed by Ponel and Coope (1990) to the classical Older Dryas. At Roustières the story is quite different since there is a discreet but continuous record of cold adapted taxa throughout the LGI, including Princidium bipunctatum, Helophorus glacialis, Eucnecosum brachypterum, Aphodius mixtus, Potamonectes griseostriatus, Tachinus elongatus (but not Agabus arcticus which shows its only occurrence later in the sequence, during the Younger Dryas). This discrepancy in the cold fauna records between two relatively close sites confirms that colder conditions probably prevailed at Roustieres due to higher altitude. In these conditions, it seems probable that the record in the insect sequence of a subtle cold spell such as the Older Dryas may be blurred by an overall markedly colder fauna. As also pointed out by Lemdahl (2000) in Switzerland, altitude was undoubtedly a major parameter which has specifically modulated the impact of Lateglacial climate variability on past insect community changes.
An overview of existing syntheses on the Lateglacial period confirms that the LGI was marked by a first rapid warming followed by a decreasing temperature trend interrupted by several minor cool reversals during the Allerød (Lotter et al., 2012). However, this general warming in Europe is not recorded everywhere with the same intensity (for example in central Europe, see Feurdean et al., 2014) and did not occur even with a common pattern. At Gerzensee (in Switzerland), minor cooling events were recorded (Ammann, 2000; Brooks and Heiri, 2013; van Raden et al., 2013) while in Norway, a slight warming and drought are documented in several profiles (Birks et al., 2014).

At Roustières, occurrences of cold adapted Coleoptera are quite continuous, excepted at ca. 13,000 cal. BP while cold adapted chironomids disappeared during the Allerød in Switzerland (Samartin et al., 2012). This gap in the curve is also synchronous with a transitory optimum of Artemisia. It might be considered that these two changes in the ecosystem are contradictory since development of steppic herbs suggest a colder climate while the absence of cold-adapted insects rather indicates a possible warming. However, looking more closely, it may be that the cold adapted coleopteran curve only represents Helophorus glacialis, which requires melting snow during summer. As a result, it can be hypothesized that during this event (Fig. 6), summer temperatures lowered so that this beetle was unable to achieve it lifecycle without snow melting (low values of running water Coleoptera also support this hypothesis of absence of runoff and of snow melting, see Fig. 6), or a marked dryness occurred at that time.

The latter hypothesis could be contradictory to what is observed at Gerzensee at this period since a high lake-level is reconstructed for the Gerzensee cold oscillation/IACP (Magny, 2013). However, the author describes a very low lake level phase preceding this episode which could be compared to what is recorded at Roustières in the late Allerød. Moreover, it can be also assumed that the location of Roustières necessarily implies that the site was submitted to a more continental climatic regime, with possible dryness during cold episodes. This point remains debatable, but the concomitance of the disappearance of cold adapted beetle, the rise of Artemisia and the lowering of running water Coleoptera strongly suggests a relatively cold and dry climatic regime as it was also reconstructed for some sites in Norway (Birks et al., 2014).

Following the LGI, the maximum of cold adapted Coleoptera is reached at Roustières during the Younger Dryas (Fig. 6), which perfectly illustrates the impact of the drastic and global cold climatic event on ecosystems, turning back to steppic grasslands in the Aubrac, but also at larger scale (Lotter et al., 2000; Magny et al., 2001; Feurdean et al., 2008; Heiri et al., 2014). Several studies have attempted to quantify this sudden cooling, with a drop in mean temperatures estimated to up to $3^{\circ}$ (Heiri et al., 2014), $5^{\circ}$ (von Grafenstein et al., 2000), even $10^{\circ}$ (Lotter et al., 2000), depending on proxies used for the reconstruction and the altitude of each site. At Roustière, there is no doubt that particularly cold conditions prevailed during the Younger Dryas, marked by both the absence of trees and shrubs, and predominance of cold adapted beetles (Fig. 6).

\subsection{The Holocene: the rise of forests}

Forest beetles, or beetles associated with trees, are uncommon throughout the sequence, so comparison with arboreal pollen data is not easy. One of the most abundant pollen taxon in this sequence is Pinus. Coleopteran assemblages are completely devoid of species associated with conifers, and we may reasonably assume that the presence of so many Pinus pollen grains results in long distance transport, as already observed in many Lateglacial mountain sites. Two tree genera occur regularly from the onset of the LGI, Salix and Betula, but no Coleoptera strictly associated with them were found in the record. It is possible that at least a fraction of the pollen deposited here (especially during the coldest episodes such as the Younger Dryas) was produced by species resistant to very cold conditions, e.g., dwarf Salix or Betula nana. 
Interestingly, the latter is still surviving today in some relictual isolated localities in the Massif Central, in the Margeride region (Souchon, 1965).

Among other deciduous trees, Ulmus, Corylus and Quercus present a similar curve, with a strong increase starting in the middle of the Preboreal. The only occurrence of Quercus associated Coleoptera (the weevil Rhynchaenus quercus) is recorded in sample 610-630, in perfect agreement with the pollen curve which reaches its maximum at the same time. Several specimens of the elm leaf beetle Galerucella luteola have been identified at the very beginning of the Ulmus curve. It shows that elm was probably well represented nearby, even when its pollen was present at the same time in such small quantities that it could be considered as the result of long distance transport. Contrary to other sites in Massif Central (Ponel and Gadbin, 1988; Ponel and Coope, 1990), it was not possible to identify any Corylus dependent Coleoptera (such as the weevil Curculio nucum), but considering the scarcity of tree adapted beetles as a whole at this site it is not reasonable to conclude that hazel was absent from the area.

These results raise the question of possible refugia for mesophilous trees to the south of Aubrac, in the Cévennes slopes: the rapid expansion of deciduous Quercus and its local presence evidenced by oakdependent beetle at ca $9850 \mathrm{cal}$. BP supports this hypothesis.

5.3. Hydro-climatic changes at the transition Lateglacial-Holocene: untangling runoff and precipitation change with insect/pollen comparisons

A focus on the period of major faunal changes at the transition Younger Dryas-Holocene (dated to 11,700 BP from the age-depth model, Fig. 3, Fig. 6) reveals an interesting pattern of events:

-the cold insect fauna disappears completely and definitively from the sequence; as described above most of these taxa (such as Helophorus glacialis) are adapted to harsh environments and need the presence of snow patches during summer to complete their life cycle,

-at the same time, the running water Coleopteran fauna shows a marked peak of abundance after a period of impoverishment during the Younger Dryas, and sustained numbers during the previous period, the Lateglacial interstadial,

-simultaneously with the peak of running water Coleoptera, the plant microfossil record shows a strong peak of Isoetes (Fig. 6).

In Massif Central lakes the dominant Isoetes species are I. lacustris and I. echinospora, which have similar ecological requirements and distributions. Both are subaquatic species living below $50 \mathrm{~cm}$ depth in lakes (and sometimes in much deeper conditions), in clear and acid waters with a gravelly or sandy bottom, in volcanic and granitic regions. Both are frequent in Aubrac and beyond in Massif Central, but occur also in the Pyrénées chain and in the Vosges, and in few lowland regions, such as Brittany where they are possibly extinct. Elsewhere in Europe they are much more abundant in nordic countries (Prelli, 2001). The strong rise in the Isoetes record suggests that ecological conditions are much more favourable to this taxon at the very beginning of the Holocene, and should be interpreted as a marked rise in the lake water level.

In brief, the hydrological changes reconstructed from our data at the transition between Younger Dryas and Holocene can be summarized as follows: the warming at the end of the Younger Dryas leads to reactivate the rivulet network around the lake (indicated by the expansion of running water beetles), in response to rapid melting of the snow cover during increasingly warmer summers (indicated by the sudden disappearance of snow patch beetles). This snow melting is correlated with a strong input of water into the depression of Roustières which is now favourable to a bloom of Isoetes. Such a possible scenario does not imply necessarily an increase of rainfall at this period. This result is important since lacustrine water level changes are often used as indicator of hydrological regime changes. In the French Jura and in Italy, lacustrine records of Younger Dryas are characterized by a rapid rise in lake-level followed by a lowering trend (Magny et al., 2001, 2006a, 2006b). Therefore, if we assume that the second part of Younger Dryas was characterized in Europe by a warming and a marked drought, the palaeoecological record of Roustières cannot be interpreted in terms of precipitation changes but illustrates actually the rapid runoff generated by snow melting in the watershed.

\section{Conclusion}

This multi-proxy palaeoenvironmental record at Roustières provides a detailed reconstruction of environmental changes during the Lateglacial and early Holocene in the Aubrac. This study represents the only contribution of fossil beetles to the knowledge on Lateglacial environmental changes in this part of Massif Central. By comparing this proxy to pollen record, it has been possible to:

(i) evaluate the structure of landscapes which occupied the Aubrac plateau during the whole Lateglacial,

(ii) reconstruct the timing of recolonization by vegetation of the area following the deglaciation.

A notable feature is that the relatively high altitude of the site and the continental climate has certainly played a major role in the relative stability of communities settled by the end of the Oldest Dryas. While vegetation dynamics followed the "classical pattern" observed in European mountains, it has been shown that insect communities were characterized by the persistence of herb dependent Coleoptera and of cold adapted taxa, reaching a peak during the Younger Dryas climatic reversal. Due to the high altitude and the cold climate of the Aubrac plateau, it remains difficult to identify the impact of minor cold oscillations on such mountain ecosystems. Therefore, we can assume that the present day landscape around the site is not really different from what could have been observed during the Lateglacial, but for totally different reasons: the treeless Lateglacial landscape was driven by harsh climatic conditions, whereas the predominantly open landscape that prevails today is modelled by human pastoral and agricultural activities!

Aquatic and snow patch Coleoptera associated with pollen data provide an original scenario concerning hydrological changes at the transition Lateglacial-Holocene: running water Coleoptera are dependent on highly oxygenated water and are rare or absent in lacustrine standing water. Therefore their occurrences in quite high numbers in the coleopteran record at Roustières is clearly a hint for an increased runoff of the tributaries feeding the former lake. At the same time, snow patch Coleoptera numbers collapse, suggesting a massive and rapid melting of the snow cover around the site, whereas pollen of aquatic plants growing in deep water reaches a peak. These three events are obviously correlated with the Holocene warming. The beetle sequence of Roustières is particularly interesting since it shows that comparison of beetle + pollen records is an excellent and promising tool for reconstructing the major hydrological changes that herald the climatic improvement at the transition Lateglacial-Holocene. We suggest here that the combined record of running water beetles, snow dependent beetles and pollen of deep water aquatic plants should be considered as a reliable indicator of snow cover melting and lacustrine water level change in future multiproxy palaeoecological studies.

Lastly, we suggest that the identification of tree-dependent insects in palaeoecological records is essential for reconstructing with accuracy postglacial recolonization of mesophilous ligneous plants: the local presence of a particular tree species can be better evidenced established from a fossil occurrence of an insect (trophically dependent to this tree) than fossil pollen of the same tree. At Roustières, observations of the elm leaf beetle (Galerucella luteola) or the oak weevil (Rhynchaenus quercus) during the early Holocene suggest that 1 / elm and oak pollen has probably a local origin, 2/ the recolonization of Aubrac mountains by these trees was made possible from nearby refugia (probably located in warmer limestone valleys of Cévennes, Quercy and Périgord). 


\section{Acknowledgments}

This study was funded by the CNRS-Eclipse program (project title: "Lake level changes during the Late and Postglacial in the Aubrac Mountain, in connection with climate changes and human impact"). Radiocarbon analysis was done by J.-P. Dumoulin and C. Moreau at the "Laboratoire de Mesure du Carbone 14", CEA-ARTEMIS facility, Gif-surYvette (France). David Smith and an anonymous reviewer helped with the English and contributed to improve the paper.

\section{References}

Ammann, B., 2000. Biotic responses to rapid climatic changes: introduction to a multidisciplinary study of the Younger Dryas and minor oscillations on an altitudinal transect in the Swiss Alps. Palaeogeogr. Palaeoclimatol. Palaeoecol. 159, 191-201.

Ammann, B., van Leeuwen, J.F.N., van der Knaap, W.O., Lischke, H., Heiri, H., Tinner, W. 2013. Vegetation responses to rapid warming and to minor climatic fluctuations during the Late-Glacial Interstadial (GI-1) at Gerzensee (Switzerland). Palaeogeogr. Palaeoclimatol. Palaeoecol. 391, 40-59.

Beaulieu, J.-L. de, Pons, A., Reille, M., 1982. Recherches pollenanalytiques sur l'histoire de la végétation de la bordure nord du massif du Cantal (Massif Central, France). Pollen Spores 24, 251-300.

Beaulieu, J.-L. de, Pons, A., Reille, M., 1984. Recherches pollenanalytiques sur l'histoire de la végétation des Monts du Velay (Massif Central, France). In: Lang, G. (Ed.), Festschrift Max Welten. Diss. Bot. Vol. 72, pp. 45-70.

Beaulieu, J.-L. de, Pons, A., Reille, M., 1985. Recherches pollenanalytiques sur l'histoire tardiglaciaire et holocène de la végétation des monts d'Aubrac (Massif Central, France). Rev. Palaeobot. Palynol. 44, 37-80.

Beaulieu, J.-L. de, Pons, A., Reille, M., 1988. Histoire de la végétation du Massif Centra (France) depuis la fin de la dernière glaciation. Cah. Micropaleontol. NS 3 (4), 5-60.

Beaulieu, J.-L. de, Andrieu-Ponel, V., Reille, M., Grüger, E., Tzedakis, C., Svobodova, H. 2001. An attempt at correlation between the Velay pollen sequence and the Middle Pleistocene stratigraphy from central Europe. Quat. Sci. Rev. 20, 1593-1602.

Birks, H.H., Aarnes, I., Bjune, A.E., Brooks, S.J., Bakke, J., Kühl, N., Birks, H.J.B., 2014 Lateglacial and early-Holocene climate variability reconstructed from multi-proxy records on Andøya, northern Norway. Quat. Sci. Rev. 89, 108-122.

Björck, S., Walker, M.J.C., Cwynar, L., Johnsen, S.J., Knudson, K.-L., Lowe, J.J., Wohlfarth, B., Members, I.N.T.I.M.A.T.E., 1998. An event stratigraphy for the last termination in the North Atlantic region based on the Greenland Ice Core record: a proposal by the INTIMATE group. J. Quat. Sci. 13, 283-292.

Blaauw, M., 2010. Methods and code for "classical" age-modelling of radiocarbon sequences. Quat. Geochronol. 5, 512-518.

Boyce, D., 2004. A Review of the Invertebrate Assemblage of Acid Mires. English Nature Peterborough

Brooks, S.J., Heiri, O., 2013. Response of chironomid assemblages to environmental change during the early Late-glacial at Gerzensee, Switzerland. Palaeogeogr. Palaeoclimatol. Palaeoecol. 391, 90-98.

Colin, F., 1966. Le volcanisme de l'Aubrac. Thèse, Clermond-Ferrand (330 p).

Coope, G.R., 1986. Coleoptera Analysis. In: Berglund, B.E. (Ed.), Handbook of Holocene Palaeoecology and Palaeohydrology. Wiley \& Sons, Chichester, pp. 703-713.

Coope, G.R., 1998. Insects. In: Preece, R.C., Bridgland, D.R. (Eds.), Late Quaternary Environment Change in North-west Europe: Excavations at Holywell Coombe, South-east England. Chapman \& Hall, London, pp. 213-233.

Coope, R., 2004. Quaternary climatic changes - what can we learn from history? ESS Bulletin. 2, pp. 57-75

Core Team, R., 2012. R: A Language and Environment for Statistical Computing. R Foundation for Statistical Computing, Vienna, Austria (ISBN 3-900051-07-0).

Dansgaard, W., Johnsen, S.J., Clausen, H.B., Dahl-Jensen, D., Gundestrup, N.S., Hammer, C.U., Hvidberg, C.S., Steffensen, J.P., Sveinbjornsdottir, A.E., Jouzel, J., Bond, G., 1993. Evidence for general instability of past climate from a 250-kyr ice-core record. Nature $364,218-220$

Doche, B., 1976. L'Aubrac: analyse des relations entre le milieu naturel et son utilisation par l'homme. Documents de cartographie écologique. 18 pp. 57-76.

Doguet, S., 1994. Coléoptères Chrysomelidae 2 (Alticinae). Fédération française des Sociétés de Sciences naturelles, Paris.

Eicher, U., Siegenthaler, U., 1976. Palynological and oxygen isotope investigation on Lateglacial sediment cores from Swiss lakes. Boreas 5, 109-117.

Faegri, K., Iversen, J., 1975. Textbook of Pollen Analysis. 3rd edition. Munksgaard, Copenhagen.

Feurdean, A., Klotz, S., Brewer, S., Mosbrugger, V., Tămaş, T., Wohlfarth, B., 2008. Lateglacial climate development in NW Romania - comparative results from three quantitative pollen-based methods. Palaeogeogr. Palaeoclimatol. Palaeoecol. 265, 121-133.

Feurdean, A., Perşoiu, A., Tanţău, I., Stevens, T., Magyari, E.K., Onac, B.P., Marković, S Andrič, M., Connor, S., Fărcas, S., Gałka, M., Gaudeny, T., Hoek, W., Kolaczek, P., Kuneš, P., Lamentowicz, M., Marinova, E., Michczyńska, D.J., Perşoiu, I., Płóciennik, M., Słowiński, M., Stancikaite, M., Sumegi, P., Svensson, A., Tămaş, T., Timar, A. Tonkov, S., Toth, M., Veski, S., Willis, K.J., Zernitskaya, V., 2014. Climate variability and associated vegetation response throughout Central and Eastern Europe (CEE) between 60 and 8 ka. Quat. Sci. Rev. 106, 206-224

Finsinger, W., Tinner, W., van der Knaap, W.O., Ammann, B., 2006. The expansion of hazel (Corylus avellana L.) in the southern Alps: a key for understanding its early Holocene history in Europe? Quat. Sci. Rev. 25, 612-631.

Gandouin, E., Rioual, P., Pailles, C., Brooks, S.J., Ponel, P., Guiter, F., Djamali, M., Andrieu-Ponel, V., Birks, H.J.B., Leydet, M., Belkacem, D., Haas, J.N., Van der Putten, N., Beaulieu, J.-L.d., 2016. Environmental and climate reconstruction of the late-glacial-Holocene transition from a lake sediment sequence in Aubrac, French Massif Central: chironomid and diatom evidence. Palaeogeogr. Palaeoclimatol. Palaeoecol. 461, 292-309.
Grootes, P.M., Stuiver, M., White, J.W.C., Johnsen, S., Jouzel, J., 1993. Comparison of oxygen isotope records from the GISP2 and GRIP Greenland ice cores. Nature 366, 552-554. Heiri, O., Koinig, K.A., Spötl, C., Barrett, S., Brauer, A., Drescher-Schneider, R., Gaar, D., IvyOchs, S., Kerschner, H., Luetscher, M., Moran, A., Nicolussi, K., Preusser, F., Schmidt, R., Schoeneich, P., Schwörer, P., Sprafke, T., Terhorst, B., Tinner, W., 2014. Palaeoclimate records 60-8 ka in the Austrian and Swiss Alps and their forelands. Quat. Sci. Rev. 106, 186-205.

Holmen, M., 1987. The Aquatic Adephaga (Coleoptera) of Fennoscandia and Denmark, I. Gyrinidae, Haliplidae, Hygrobiidae and Noteridae. Brill, Scandinavian Science Press, Leiden-Copenhagen,

Juggins, S., 2003. C ${ }^{2}$ User Guide. Software for Ecological and Palaeoecological Data Analysis and Visualisation. University of Newcastle, Newcastle upon Tyne, UK.

Juggins, S., 2015. Rioja: Analysis of Quaternary Science Data, R Package Version (0.9-5) (http://cran.r-project.org/package $=$ rioja)

Koch, K., 1989-1992. Die Käfer Mitteleuropas, Ökologie 1, 2 \& 3. Goecke \& Evers, Krefeld.

Lang, G., Trautman, W., 1961. Zur spät- und nacheiszeitlichen Vegetationsgeschichte der Auvergne. Flora 150 II (1), 11-42.

Lehman, S.J., Keigwin, L.D., 1992. Sudden changes in North Atlantic circulation during the last deglaciation. Nature 356, 757-762.

Lemdahl, G., 2000. Lateglacial and Early Holocene insect assemblages from sites at different altitudes in the Swiss Alps - implications on climate and environment. Palaeogeogr. Palaeoclimatol. Palaeoecol. 159, 293-312.

Lemée, G., 1944. Evolution forestière comparée de l'Aubrac et du Cézallier au Postglaciaire. Comptes Rendus de l'Académie des Sciences Paris. 218 pp. 477-479.

Litt, T., Schmincke, H.U., Kromer, B., 2003. Environmental response to climatic and volcanic events in central Europe during the Weichselian Lateglacial. Quat. Sci. Rev. 22, 7-32.

Lotter, A.F., Eicher, U., Birks, H.J.B., Siegenthaler, U., 1992. Late-glacial climatic oscillations as recorded in Swiss lake sediments. J. Quat. Sci. 7, 187-204.

Lotter, A.F., Birks, H.J.B., Eicher, U., Hofmann, W., Schwander, J., Wick, L., 2000. Younger Dryas and Allerød summer temperatures at Gerzensee (Switzerland) inferred from fossil pollen and cladoceran assemblages. Palaeogeogr. Palaeoclimatol. Palaeoecol. 159, 349-36.

Lotter, A.F., Heiri, O., Brooks, S., van Leeuwen, J.F., Eicher, U., Ammann, B., 2012. Rapid summer temperature changes during Termination 1a: high-resolution multi-proxy climate reconstructions from Gerzensee (Switzerland). Quat. Sci. Rev. 36, 103-113.

Lucht, W.H., 1987. Die Käfer Mitteleuropas, Katalog. Goecke \& Evers, Krefeld.

Lumaret, J.-P., Lobo, J.M., Jay-Robert, P., 1996. Catalogue et Atlas des Scarabéides Laparosticti endémiques de France. Service du Patrimoine Naturel/IEGB/MNHNOPIE, Paris.

Magny, M., 2013. Climatic and environmental changes reflected by lake-level fluctuations at Gerzensee from 14,850 to 13,050 yr BP. Palaeogeogr. Palaeoclimatol. Palaeoecol. 391, 33-39.

Magny, M., Guiot, J., Schoellammer, P., 2001. Quantitative reconstruction of Younger Dryas to mid-Holocene paleoclimates at Le Locle, Swiss Jura, using pollen and lakelevel data. Quat Res. 56, 170-180.

Magny, M., Aalbersberg, G., Bégeot, C. Benoit-Ruffaldi, P., Bossuet, G., Disnar, J.R., Heiri, O, Laggoun-Defarge, F., Mazier, F., Millet, L., Peyron, O., Vannière, B., Walter-Simonnet, A.-V., 2006a. Environmental and climatic changes in the Jura mountains (eastern France) during the Lateglacial-Holocene transition: a multi-proxy record from Lake Lautrey. Quat. Sci. Rev. 25, 414-445.

Magny, M., Beaulieu, J.-L.d., Drescher-Schneider, R., Vannière, B., Walter-Simonnet, A.-V., Millet, L., Bossuet, G., Peyron, O., 2006b. Climatic oscillations in central Italy during the Last Glacial-Holocene transition: the record from Lake Accesa. J. Quat. Sci. 21, $311-320$

Marggi, W., 1992. Faunistik der Sandlaufkäfer und Laufkäfer der Schweiz (Cicindelidae \& Carabidae), Teil 1. Centre suisse de cartographie de la faune, Neuchâtel.

Moreno, A., Svensson, A., Brooks, S.J., Connor, S., Engels, S., Fletcher, W., Genty, D., Heiri, O., Labuhn, I., Perşoiu, A., Peyron, O., Sadori, L., Valero-Garcés, B., Wulf, S., Zanchetta, G., 2014. A compilation of Western European terrestrial records 60-8 ka BP: towards an understanding of latitudinal climatic gradients. Quat. Sci. Rev. 106, 167-185.

Nilsson, A., Holmen, M., 1995. The Aquatic Adephaga (Coleoptera) of Fennoscandia and Denmark, II. Dytiscidae. Brill, Scandinavian Science Press, Leiden-Copenhagen.

Paulian, R., Baraud, J., 1982. Faune des Coléoptères de France. II. Lucanoidea et Scarabaeoidea. Encyclopédie Entomologique, XLIII. Lechevalier, Paris,

Poizat, M., Rousset, C., 1975. Les calottes de glace quaternaires des Monts d'Aubrac (Massif Central, France): caractéristiques, contexte paléoclimatique. Rev. Géogr. Phys. Géol. Dyn. 12, 171-190

Ponel, P., Coope, G.R., 1990. Lateglacial and Early Flandrian Coleoptera from La Taphanel, Massif Central, France: climatic and ecological implications. J. Quat Sci. 5, 235-249.

Ponel, P., Gadbin, C., 1988. Apports de la paléoentomologie à un épisode de l'histoire de la végétation des bords du lac d'Issarlès. C. R. Acad. Sci. Paris 307 (III), 755-758.

Ponel, P., Etlicher, B., Beaulieu, J.-L. de, Debard, E., Thinon, M., Vasari, A., Petiot, R., 1991. La fin de la dernière glaciation dans le Cantal (France): la tourbière de la Taphanel et son environnement. Quaternaire 2, 147-163.

Ponel, P., Jay, P., Lumaret, J.-P., 1995. Past and present changes in the coleopteran fauna since the end of the last glaciation: the case of the Western Alps and the Apennines. Potential ecological impacts of climate change in the Alps and Fennoscandian mountains. In: Guisan, A., Holten, J., Spichiger, R., Tessier, L. (Eds.), Conserv. Jard. Bot. Genève, pp. 159-172.

Prelli, R., 2001. Les fougères et plantes alliées de France et d'Europe occidentale. Belin, Paris.

Puech, F. 2010. Document d'objectif du site N FR 9101352 “Plateau de l'Aubrac", Volume 1. Communauté de Communes de l'Aubrac lozérien.

Rasmussen, S.O., Andersen, K.K., Svensson, A.M., Steffensen, J.P., Vinther, B.M., Clausen, H.B., Siggaard-Andersen, M.-L., Johnsen, S.J., Larsen, L.B., Dahl-Jensen, D., Bigler, M., Röthlisberger, R., Fischer, H., Goto-Azuma, K., Hansson, M.E., Ruth, U., 2006. Greenland ice core chronology for the last glacial termination. J. Geophys. Res. 111, D06102 (http://dx.doi.org/10.1029/)

Rasmussen, S.O., Bigler, M., Blockley, S.P., Blunier, T., Buchardt, S.L., Clausen, H.B., Cvijanovic, I., Dahl-Jensen, D., Johnsen, S.J., Fischer, H., Gkinis, V., Guillevic, M., Hoek, 
W.Z., Lowe, J.J., Pedro, J.B., Popp, T., Seierstad, I.K., Steffenson, J.P., Svensson, A.M., Vallelonga, P., Vinther, B.M. Walker, M.J.C. Wheatley, J.J., Winstrup, M. 2014. A stratigraphic framework for abrupt climatic changes during the last Glacial period based on three synchronized Greenland ice-core records: refining and extending the INTIMATE event stratigraphy. Quat. Sci. Rev. 106, 14-28.

Reille, M., Beaulieu, J.-L. de, 1988. History of the Würm and Holocene vegetation in western Velay (Massif Central, France): a comparison of pollen analysis from three corings at Lac du Bouchet. Rev. Palaeobot. Palynol. 54, 233-248.

Reimer, P.J., Bard, E., Bayliss, A., Beck, J.W., Blackwell, P.G., Bronk Ramsey, C., Grootes, P.M., Guilderson, T.P., Haflidason, H., Hajdas, I., Hatté, C., Heaton, T.J., Hoffmann, D.L., Hogg A.G., Hughen, K.A., Kaiser, K.F., Kromer, B., Manning, S.W., Niu, M., Reimer, R.W., Richards, D.A., Scott, E.M., Southon, J.R., Staff, R.A., Turney, C.S.M., van der Plicht, J., 2013. IntCal13 and MARINE13 radiocarbon age calibration curves $0-50,000$ years cal BP. Radiocarbon 55, 1869-1887.

Samartin, S., Heiri, O., Vescovi, E., Brooks, S.J., Tinner, W., 2012. Lateglacial and early Holocene summer temperatures in the southern Swiss Alps reconstructed using fossil chironomids. J. Quat. Sci. 27, 279-289.

Schwander, J., Eicher, U., Ammann, B., 2000. Oxygen isotopes of lake marl at Gerzensee and Leysin (Switzerland), covering the Younger Dryas and two minor oscillations, and their correlation to the GRIP ice core. Palaeogeogr. Palaeoclimatol. Palaeoecol. 159, 203-214.

Shakun, J.D., Carlson, A.E., 2010. A global perspective on Last Glacial Maximum to Holocene climate change. Quat. Sci. Rev. 29, 1801-1816.

Siegenthaler, U., Eicher, U., Oeschger, H., Dansgaard, W., 1984. Lake sediments as continental $\delta^{18} 0$ records from the glacial/post-glacial transition. Ann. Glaciol. 5, 149-152.

Smith, D., Whitehouse, N., Bunting, M.J., Chapman, H., 2010. Can we characterise "openness' in the Holocene palaeoenvironmental record? Modern analogue studies of insect faunas and pollen spectra from Dunham Massey deer park and Epping Forest. England. The Holocene 20, 215-229.

Souchon, C., 1965. Étude de la localisation stationnelle du Betula nana L. en Margeride. Revue des sciences naturelles d'Auvergne. 31 pp. 59-72.

Stuiver, M., Grootes, P.M., Braziunas, T.F., 1995. The GISP2 $\delta^{18} \mathrm{O}$ climate record of the past 16,500 years and the role of the sun, ocean, and volcanoes. Quat. Res. 44, 341-354.

Tronquet, M., 2014. Catalogue des Coléoptères de France. Association Roussillonnaise d'Entomologie, Perpignan (Coord.).

Van Raden, U.J., Colombaroli, D., Gilli, A., Schwander, J., Bernasconi, S.M., van Leeuwen, J., Leuenberger, M., Eicher, U., 2013. High-resolution late-glacial chronology for the Gerzensee lake record (Switzerland): $\delta^{18} \mathrm{O}$ correlation between a Gerzensee-stack and NGRIP. Palaeogeogr. Palaeoclimatol. Palaeoecol. 391, 13-24.

Villiers, A., 1978. Faune des Coléoptères de France I. Cerambycidae. Encyclopédie Entomologique XLII. Lechevalier, Paris.

Von Grafenstein, U., Eicher U., Erlenkeuser, H. Ruch, P. Schwander, J., Ammann, B., 2000 Isotope signature of the Younger Dryas and two minor oscillations at Gerzensee (Switzerland): palaeoclimatic and palaeolimnologic interpretation based on bulk and biogenic carbonates. Palaeogeogr. Palaeoclimatol. Palaeoecol. 159, 215-229.

Von Grafenstein, U., Belmecheri, S., Eicher, U., van Raden, U.J., Erlenkeuser, H., Andersen N., Ammann, B., 2013. The oxygen and carbon isotopic signatures of biogenic carbonates in Gerzensee, Switzerland, during the rapid warming around 14,685 years BP and the following interstadial. Palaeogeogr. Palaeoclimatol. Palaeoecol. 391, 25-32.

Zanetti, A., 1987. Coleoptera Omaliinae, Fauna d'Italia. 25. Calderini, Bologna. 